\title{
VOLATILITY FORECASTING PERFORMANCE OF SMOOTH TRANSITION EXPONENTIAL SMOOTHING METHOD: EVIDENCE FROM MUTUAL FUND INDICES IN MALAYSIA
}

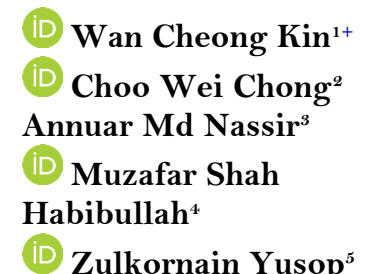

Article History

Received: 5 August 2021 Revised: 10 September 202 Accepted: 1 October 2021 Published: 29 October 2021

\section{Keywords}

Smooth transition exponential Smoothing

GARCH

Volatility forecasting

Mutual funds

Model confidence set

Outliers.

JEL Classification: C53; C58; G17.

\author{
${ }^{\text {}}$ School of Graduate Studies, Universiti Putra Malaysia, Serdang, Malaysia; \\ Department of Business Studies, HELP University, Kuala Lumpur, \\ Malaysia. \\ 'Email: cheongkin.wan@help.edu.my Tel: +60192763350 \\ School of Business and Economics, Universiti Putra Malaysia, Serdang, \\ Malaysia. \\ ${ }^{2}$ Email:wcchoo@upm.edu.my Tel: +60124335168 \\ ${ }^{3}$ School of Economics and Management, Xiamen University Malaysia, \\ Sepang, Malaysia. \\ ${ }^{s}$ Email:annuar.nassir@xmu.edu.my Tel: +60193898015 \\ ${ }^{4,5}$ Putra Business School, Universiti Putra Malaysia, Serdang, Malaysia. \\ Email:muzafar@putrabs.edu.my Tel: +60122143451 \\ ${ }^{5}$ Email: zulkornain@putrabs.edu.my Tel: +60136987845
}

\section{ABSTRACT}

This paper aims to empirically compare the performance of the smooth transition exponential smoothing (STES) method against the well-known generalized autoregressive conditional heteroskedasticity (GARCH) model in one-step-ahead volatility forecasting. While the GARCH model captured most of the stylized facts of the financial time series, threats of outliers in the leptokurtic distributed series remain unresolved. The study compared volatility forecasting performance of a total of 22 models and methods comprising STES, GARCH, and some ad-hoc forecasting. The daily returns of seven mutual fund indices (derived from 57 individual equity mutual funds) under two different economic conditions (sub-periods) were applied across all competing models. Findings revealed that the STES method with error and absolute error as transition variables emerged as the best post-sample volatility forecasting model in both sub-periods with and without financial crisis impact, as verified by model confidence set (MCS) procedure. The implications based on the results are: (1) both the sign and size of yesterday's news shock have an impact on today's volatility; (2) the STES method is resilient to outliers, and hence superior to GARCH and other volatility forecasting approaches examined. This study contributes an empirical approach in forecasting the risk of mutual funds investment for investors and fund managers, as well as extending the scope of volatility forecasting literature into the less explored mutual funds.

Contribution/Originality: This study contributes to the existing literature as the first to employ the robust STES method in forecasting the volatility of mutual funds. STES method outperformed GARCH with robustness of results verified by the MCS procedure. The seven newly created fund indices from 57 individual funds have enabled macro-analysis of fund risk. 


\section{INTRODUCTION}

In the context of financial investment, volatility is the quantified measurement of risk arising from an uncertain situation impacting investment return. Although volatility is not the same as risk, its interpretation from the perspective of uncertainty becomes a crucial element in investment decisions and financial risk management. As such, accurate forecasting of an asset's return volatility is the prerequisite for assessing investment risk (Poon \& Granger, 2003). Undeniably, measuring volatility is critical to portfolio risk management, securities pricing, and policies management. The emergence of large amount of literature on volatility forecasting over the past decades focusing predominantly on modeling and forecasting volatility signifies its importance.

Before the emergence of volatility studies, forecasting the volatility of financial assets has never been a topic of importance. The Random Walk Theory advocated that successive prices of an asset are unrelated or random. Historic prices are not relevant to the prediction of future prices (Figlewski, 1997). In short, the Random Walk Theory asserts that the best forecast for tomorrow's pricing is today's price. However, Mandelbrot (1963), in his seminal work, argued that financial time series are not normally and independently distributed. His findings provide insight into the existence of the "volatility clustering" phenomenon in financial time series, therefore invalidating the Random Walk Theory. The characteristics of financial time series often consist of high-frequency observations, which can intensify the influence of non-systematic factors such as the impact of news, triggering a reaction from investors which eventually forms the basis for volatility persistency over time. The variance of the random error term of financial time series is time-varying (non-constant) or heteroskedastic in nature. Poon \& Granger (2003) reviewed 93 published works and working papers concerning the performance of various volatility forecasting models emphasizing the risk attributed to the unique stylized facts of financial time series. There are several salient features about financial time series and financial market volatility that is now well documented. These include fat tail distributions of risky asset returns, volatility clustering, asymmetry and mean reversion, and co-movements of volatilities across assets and financial markets. More recent research found that the correlation among volatilities is stronger than that among returns, and both tend to increase during bear markets and financial crises (Poon \& Granger, 2003).

Although volatility is unobservable and latent, it persists over time (Bollerslev, Chou, \& Kroner, 1992; Chou, 1988; Choudhry, 1995). This fact has enabled volatility to be modeled and forecast statistically. The GARCH (generalized autoregressive conditional heteroskedasticity) model by Bollerslev (1986) is an improvised version of the original ARCH (autoregressive conditional heteroskedasticity) model first introduced by Engle (1982) and has become an essential tool in examining heteroskedasticity in financial time series data. Extension of the GARCH model into the IGARCH (integrated GARCH) model by Engle \& Bollerslev (1986) coupled with other asymmetric GARCH models, particularly EGARCH (exponential GARCH) by Nelson (1991) and GJR-GARCH by Glosten, Jagannathan, \& Runkle (1993) has prompted the emergence of large quantity of literature on volatility studies, stocks in particular. However, volatility studies on mutual funds are scarce. A study of more than 300 different GARCH model specifications by Hansen \& Lunde (2005) confirmed the supremacy of the GARCH model in postsample volatility forecasting.

However, Taylor (2004a); Taylor (2004b) opened up new possibilities for volatility forecasting studies where his less explored STES (Smooth Transition Exponential Smoothing) method outperformed the well-known GARCH, as documented in his study of weekly volatility forecasting of time series for eight stock indices across both developed and developing markets using realized volatility generated from daily returns. To the best knowledge of the authors, the STES method has not been employed in forecasting the volatility of mutual funds thus far, either internationally or domestically within Malaysia. Furthermore, the application of the GARCH models in mutual funds is possibly non-existent in the Malaysian context with few mutual fund volatility studies from overseas (Busse, 1999; Tang, Wang, \& Xu, 2012; Xie \& Huang, 2013). Past studies on mutual funds found inconsistencies between funds' objectives and their risk-return relationship (Annuar, Shamsher, \& Ngu, 1997; 
DiBartolomeo \& Witkowski, 1997; Jin \& Yang, 2004; Kim, Shukla, \& Tomas, 2000; Mohamad \& Nassir, 1995). The inability of fund managers in "market timing" and "selectivity" (Chen, Adams, \& Taffler, 2013; Haroon, Sadaqat, Jebran, \& Ali Memon, 2018; Vieira, Neto, \& Da Mota, 2017) further pose a greater risk in mutual funds investment. These factors certainly raise concerns about the risk involved in mutual funds investment.

This paper aims to empirically verify the robustness and supremacy of the STES method against the wellknown GARCH family models and other historical volatility approaches through modeling volatility (risk) of seven equity-based private mutual funds indices (of different investment objectives) in Malaysia for two sub-periods with and without the impact of the financial crisis. The remainder of this paper is organized as follows: Section 2 provides a review of related past literature on GARCH under different error distribution assumptions and STES volatility forecasting studies; Section 3 explains the methodology and models employed; Section 4 presents the empirical results and discussion on the findings; Section 5 concludes the study with suggestions for future research.

\section{LITERATURE REVIEW}

\subsection{Mutual Funds' Risk}

The mutual fund industry commenced in Malaysia in 1959 and has now contributed a net asset value of $28.2 \%$ to the total market capitalization of Bursa Malaysia of the end of 2019. This implies its importance and growing acceptance amongst Malaysian as an alternative investment option. While mutual funds claim to offer the salient feature of risk diversification, many past studies on mutual funds revealed inconsistencies between funds' investment objectives and their risk-return relationship. DiBartolomeo \& Witkowski (1997) found 40\% of mutual funds examined have misclassified objectives. Kim et al. (2000) found that 33\% of funds have deviated severely from their original objectives. Annuar et al. (1997) found riskier growth funds have only 53\% risk diversification, while lower risk balanced funds have $60 \%$ risk diversification.

The inability of fund managers to time the market and select appropriate stocks for mutual funds' portfolios to diversify risk and optimize returns (Chen et al., 2013; Haroon et al., 2018; Vieira et al., 2017) further compounded the risk factor. Fund managers tend to disregard fund objectives in their daily trading operation due to "peer pressure" and "accountability to investment return", and therefore traded off risk diversification for riskier returns (Kim et al., 2000). This warrants a need to model and forecast risk in mutual funds investment.

\subsection{Limitations of GARCH Models and Error Term Distribution Assumption}

The generalized autoregressive conditional heteroskedasticity (GARCH) framework revolves around an autoregressive process where today's volatility (conditional variance) is conditioned on yesterday's squared error (due to news impact) and yesterday's conditional variance (Bollerslev, 1986). The GARCH model, regarded as the main workhorse of empirical volatility studies, offers flexible lag structures capable of accommodating longer memory effects attributed to the persistency of volatility over time. The integrated GARCH (IGARCH) is tasked to address the issue of volatility persistency (Bollerslev \& Engle, 1993; Engle \& Bollerslev, 1986). Meanwhile, both the symmetric GARCH and IGARCH models address the issue of excess kurtosis; however, the issue of skewness remains unresolved. The asymmetrical effect arises due to positive or negative news shock of similar magnitude (or size) and produces different impacts on conditional variance (volatility) of financial assets. The logarithmic form of the exponential GARCH (EGARCH) model eliminates the restriction of the non-negativity of parameter estimates imposed in the standard GARCH model by capturing asymmetric effects (Nelson, 1991). Inspired by the seminal work of American economist Fisher Black in 1976, Glosten et al. (1993) introduced the Glosten-JagananthanRunkle GARCH (GJR-GARCH) to capture the "leverage effect" where a negative new shock exerts a greater impact on the volatility of financial assets returns than positive news of a similar magnitude. Nevertheless, the GJRGARCH is superior to the EGARCH in capturing the leverage effect, as the latter tends to produce conditional 
variance, which is even higher than the squared residual (a proxy for actual volatility) and should not be the case if the model is correctly specified (Engle \& Ng, 1993).

Many prior works of literature have predominantly skewed towards a race to establish the best volatility model based on forecasting accuracy but lack discussion on the impact of innovations of the error term. Although the strength of asymmetric GARCH models lies in their capability to capture the asymmetrical leverage effect, the error term distribution assumption does influence the accuracy of volatility forecasting of GARCH models. Three commonly examined error term distribution assumptions are Gaussian (normal), Student-t, and General Error Distribution (GED). The asymmetric EGARCH and GJR-GARCH models under Student-t error term distribution assumption were commendable in accounting for an asymmetric leverage effect documented in past strands of literature on stock volatility, both internationally (Alberg, Shalit, \& Yosef, 2008; Dritsaki, 2017; Hamilton \& Susmel, 1994; Kuhe, 2018; Wilhelmsson, 2006) and domestically (Malaysian cases) (Angabini \& Wasiuzzaman, 2011; Chong, Ahmad, \& Abdullah, 1999; Lim \& Sek, 2013; Shamiri \& Isa, 2009). Meanwhile, the stock market of different volatility characteristics supported the asymmetric GJR-GARCH with the Student-t error distribution assumption (Musa, Adamu, \& Dauran, 2020; Peters, 2001) and the symmetric GARCH under Student-t distribution (Luo, Pairote, \& Chatpatanasiri, 2017; Rana, 2020) as the best post-sample volatility forecasting models.

Although the asymmetric GARCH models are efficient in capturing volatility clustering, volatility persistency and the asymmetric GARCH capture the asymmetric leverage effect, but the assumption of a Gaussian distribution of the error term does not entirely address the issue of leptokurtosis (Peters, 2001), typically in high-frequency financial time series where the issue of outliers prevails.

\subsection{Outliers and Structural Changes Issues}

The issue of outliers or extreme values of assets returns is one of the stylized facts of financial time series, where even a standard GARCH model with a Student-t innovation of the error term is not sufficient to address the outlier issue entirely (Poon \& Granger, 2003). The presence of outliers in time series tends to cause overestimation of in-sample GARCH parameters under the maximum likelihood estimator, resulting in bias (overstated) postsample volatility forecasting (Carnero, Peña, \& Ruiz, 2012). The impact of outliers is even more prominent in a small to moderate sample size with a moderate to large magnitude of outliers (Grané \& Veiga, 2014). Removal of additive outliers is one suggested remedy which can improve the accuracy of the GARCH model in volatility forecasting. A study conducted by Franses \& Ghijsels (1999) using the Additive Outliers Corrected GARCH model found that the volatility forecasts of four out of five stock market indices had improved. The issue of addressing outliers depends on the appropriateness of the model applied in different economic conditions to ensure correct interpretation of volatility (Hossain, Akter, \& Ismail, 2021).

\subsection{Adaptive Exponential Smoothing}

The adaptive exponential smoothing method was introduced (Trigg \& Leach, 1967; Williams \& Miller, 1999) to address the shortcomings of prior exponential smoothing methods. Leveraging on the adaptive exponential smoothing methods, Taylor (2004a) introduced the Smooth Transition Exponential Smoothing (STES) method of volatility forecasting where the adaptive smoothing parameter comes in the form of a logistic function of userspecified transition variables, which is highly resilient to the issues of outliers and structural changes in time series. Taylor (2004b) applied the STES technique across eight stock indices of developed and developing economies to forecast weekly volatility and compared it against the GARCH, IGARCH, GJRGARCH, Logistic SmoothTransition GARCH, and Exponential Smooth-Transition GARCH as a comparison against five STES methods with five different transition variables, respectively. The STES method with the error and absolute error transition variables emerged as the best one-week-ahead volatility forecasting model. 
Liu, Taylor, \& Choo (2020) applied the STES method to stocks and empirically examined the resilience of STES to outliers using the different simulated magnitude of outliers. A comparison between the standard model set (comprised of four GARCH models) and the robust model set (comprising three exponential smoothing methods) revealed STES methods are the best for volatility forecasting indicated by the highest number of remaining models in the "Superior Set Models" of the Model Confidence Set procedure (Hansen, Lunde, \& Nason, 2011). The application of the STES method in volatility forecasting studies has been very limited, apart from studies by Taylor (2004a); Taylor (2004b) and Liu et al. (2020).

Past literature on the STES method has focused mainly on stock volatility studies. The findings of this study will further enrich current literature and fill the volatility forecasting gap as STES methods are applied to model volatility of seven equity mutual fund indices in Malaysia under two different sub-periods. To the best knowledge of the authors, private equity mutual fund indices time series in Malaysia have never been applied in any mutual funds' volatility studies. We raised the following hypotheses:

$H_{A A}$ The STES method outperforms GARCH models and other methods in one-day-ahead volatility forecasting of mutual fund indices return in sub-periods during a financial crisis.

$H_{I B}$ : The STES method outperforms GARCH models and other methods in one-day-ahead volatility forecasting of mutual fund indices return in sub-periods outside of a financial crisis.

\section{METHODOLOGY}

\subsection{Volatility Forecasting Models and Methods}

The analysis approach is designed to make comparison between models and methods to identify the best performing model in one-day-ahead volatility forecasting for seven equity private mutual fund indices by making comparisons between 22 models. These models are random walk; naïve forecasting; moving average; exponential weighted moving average (EWMA); EWMA optimized; GARCH models (comprising GARCH, EGARCH, IGARCH, GJR-GARCH, each under three different error term distribution assumptions of Gaussian, Student-t and GED); STES methods under five different "transition variables" of past error (E), past squared error (SE), absolute error (AE), past error and absolute error (E \& AE), past error and past squared error (E \& SE). a) Random Walk $(\mathrm{RW})$

$\mathrm{RW}$ is a historical price model where today's variance $\sigma_{t}^{2}$ is a function of yesterday's variance $\sigma_{t-1}^{2}$, which is proxied by yesterday's residual squared $\varepsilon_{t-1}^{2}$ (Poon \& Granger, 2003), specified as Equation 1:

$$
\sigma_{t}^{2}=\sigma_{t-1}^{2}=\varepsilon_{t-1}^{2}
$$

b) Naïve Variance Forecasting (NF)

NF defines today's variance $\sigma_{t}^{2}$ as an average of past squared residuals (proxy for past variances), specified as Equation 2:

$$
\sigma_{t}^{2}=\frac{1}{t-1}\left[\sum_{j=1}^{t-1} \varepsilon_{j}^{2}\right]
$$

c) Moving Average-30 days (MA-30)

MA is an extension of NF where the average of past squared residuals comes in the form of a rolling $n$ number of days. An MA-30 implies that a smooth 30-day rolling contains the latest information with older information discarded, specified as Equation 3: 


$$
\sigma_{t}^{2}=\frac{1}{30}\left[\sum_{j=t-30}^{t-1} \varepsilon_{j}^{2}\right]
$$

\section{d) Exponential Weighted Moving Averages (EWMA)}

EWMA addresses the weaknesses of MA by assigning higher weightage to more recent information and eliminating the issue of lag length determination in the form of exponential smoothing, and offering a pragmatic approach to measuring volatility, specified as Equation 4:

$$
\sigma_{t}^{2}=\beta \sigma_{t-1}^{2}+(1-\beta) \frac{1}{L} \sum_{j=1}^{L} \sigma_{t-j}^{2}
$$

where $L$ is the length of moving average and $\beta$ is the decaying factor. The JP Morgan RiskMetrics model suggested $\beta$ values of 0.94 and 0.97 for daily and weekly, respectively (Chuang, Lu, \& Lee, 2007; Mabrouk, 2017).

e) Standard GARCH $(p, q)$

The standard GARCH (p,q) model is specified in Equation 5 and Equation 6:

$$
\begin{array}{r}
r_{t}=m_{t}+\varepsilon_{t} \text { where } \varepsilon_{t}=v_{t} \sqrt{h_{t}} \text { where } v_{t} \sim N(0,1) \\
h_{t}==_{0}+\sum_{i=1}^{q} \alpha_{i} \varepsilon_{t-1}^{2}+\sum_{j=1}^{p} \beta_{j} h_{t-j}
\end{array}
$$

where is Equation 5 is the mean equation and Equation 6 is the variance equation. $r_{t}$ is the expected return of a financial asset, $m_{t}$ is the conditional mean, $\varepsilon_{t}$ is the residual series, $h_{t}$ is the conditional variance of the residual, and $v_{t}$ is the identical and independent sequence. $\omega_{0}, \alpha$ and $\beta$ are parameters to be estimated using the maximum likelihood estimation. The $\alpha$ value represents the impact of news shock on the volatility of the return of an asset, while the $\beta$ value represents volatility clustering (impact of past volatility on current volatility). A higher value of $\alpha+\beta$ implies higher volatility persistency attributed to news impact. To ensure $h_{t}$ is stationary and positive, a constraint $\alpha+\beta<1$, hence $\omega_{0}>0, \alpha \geq 0$ and $\beta \geq 0$ and $i=1, \ldots q, j=1, \ldots, p . \quad \alpha+\beta$, measures volatility persistency. The GARCH model was developed under the assumption of normality in the error term distribution where $\varphi_{t}=\varepsilon_{t} / \sqrt{h_{t}} \sim \mathrm{N}(0,1)$, and the conditional density of the error term $\varepsilon_{t}$ in the likelihood function is given as follows:

$$
\left.f\left(\varepsilon_{t} \mid \gamma, \theta_{t-i}\right)=\frac{1}{\sqrt{2 \pi h_{t}}} e^{-\left(\varepsilon_{t}^{\pi}\right.} / 2 h_{k}\right)
$$




$$
\text { where } \theta_{t-i}=\left\{\varepsilon_{t-1}, \varepsilon_{t-2}, \ldots \varepsilon_{1}\right\} \text { and } \gamma=(\mu, \omega, \alpha, \beta)
$$

Based on the likelihood function above, the corresponding log-likelihood function (LLF) is re-written as:

$\mathrm{L}(\theta, \varepsilon)=\sum_{t=2}^{T} \ln f\left(\varepsilon_{t} \mid \gamma, \theta_{t-i}\right)$ where $\varepsilon=\left(\varepsilon_{1}, \varepsilon_{2}, \ldots, \varepsilon_{T}\right)^{\prime}$

and the maximum likelihood (ML) estimator $\hat{\theta}$ is obtained by maximizing the LLF above. The ML estimator estimates the distribution or density of the error terms as a function to the parameter estimates of the conditional variance based on the likelihood function.

\section{f) Integrated $G A R C H(I G A R C H)$}

The IGARCH model was developed by Engle \& Bollerslev (1986) to specifically examine volatility persistency, specified as Equation 7:

$$
h_{t}=\sum_{i=1}^{q} \alpha_{i} \varepsilon_{t-1}^{2}+\sum_{j=1}^{p} \beta_{j} h_{t-j}
$$

where $\alpha+\beta=1$ implies an infinite variance of the unconditional distribution of the error term $\varepsilon_{t}$. The impact of current news shock on volatility will be infinitely persistent on future variance (Choudhry, 1995) could result in bias forecasting when a structural shift exists in the unconditional variance.

g) Exponential GARCH (EGARCH)

The non-negative restriction on parameter estimates in standard GARCH (p,q) has led to the introduction of the EGARCH model by Nelson (1991), specified as Equation 8:

$$
\log h_{t}=\omega+\sum_{i=1}^{q} \alpha_{i} g\left(Z_{t-i}\right)+\sum_{j=1}^{p} \beta_{j} \ln \left(h_{t-j}\right)
$$

where $g\left(Z_{t}\right)=\theta Z_{t}+\gamma\left(\left|Z_{t}\right|-E\left|Z_{t}\right|\right), Z_{t}=\varepsilon_{t} \mid \sqrt{h_{t}}$ and $E\left|Z_{t}\right|=\sqrt{\frac{2}{\pi}}$ if $Z_{t} \sim \mathrm{N}(0,1)$. The specification of $g\left(Z_{t}\right) \equiv \theta Z_{t}+\gamma\left(\left|Z_{t}\right|-E\left|Z_{t}\right|\right)$ enables the capturing of asymmetric effects. Component $\gamma\left(\left|Z_{t}\right|-E\left|Z_{t}\right|\right)$ measures the "magnitude effect" (size of the impact of news shock on volatility), while $\theta Z_{t}$ denotes the "sign effect" (asymmetrical effect) of $Z_{t-i}$. The value $\gamma=0$ signifies that no asymmetric or leverage effect exists, while $\gamma<0$ indicates the presence of a "leverage effect" implying "that negative news" exerts a greater magnitude of shock on the conditional variance (volatility). Conversely, $\gamma>0$ indicates the absence of a leverage effect but implies that a positive shock affects volatility more than negative shocks. The parameter $\theta$ measures the asymmetry effect where $\theta<0$, and a negative news shock exerts greater volatility on asset returns than a positive news shock of a similar magnitude and vice versa. 


\section{h) Glosten-Jagannanthan-Runkle GARCH (GJR-GARCH)}

Glosten et al. (1993) developed this model, which is capable of capturing the leverage effect, specified as Equation 9:

$$
h_{t}=\omega+\sum_{i=1}^{q}\left(\alpha_{i} \varepsilon_{t-i}^{2}+\gamma_{i} d_{t-i} \varepsilon_{t-i}^{2}\right)+\sum_{j=1}^{p} \beta_{j} h_{t-j}
$$

where $d_{t-i}$ is a functional index (dummy variable),; parameter $\gamma_{i}$ measures the leverage effect,; $d_{t-i}=1$ if a negative error occurs, indicated by $\varepsilon_{t-i}<0$; and $d_{t-i}=0$ if a positive error occurs, indicated by $\varepsilon_{t-i}>0$. The conditional variance (volatility) is positive when, $\omega>0, \alpha>0, \gamma \geq 0, \alpha+\gamma \geq 0$ and $\beta \geq 0$. The GJRGARCH process is deemed stationary when the following constraint $\alpha+\beta+\frac{\gamma}{2}<1$ is fulfilled. $\gamma_{i}>0$ signifies the existence of an asymmetric leverage effect. When $\gamma_{i}>0$ and $\varepsilon_{t-i}<0$ (negative news shock where the dummy $\left.d_{t-i}=1\right)$, the total impact on volatility will be larger, as indicated by $\left(\alpha+\gamma_{i}\right) \varepsilon_{t-i}^{2}$. On the other hand, when a positive error occurs, indicated by $\varepsilon_{t-i}>0$ (positive news shock where dummy $d_{t-i}=0$ ), the total impact on the conditional variance (volatility) will be smaller, as indicated by $\alpha \varepsilon_{t-\bar{i}}^{2}$.

\section{i) Smooth Transition Exponential Smoothing (STES)}

Taylor (2004a) extended the exponential smoothing method (Trigg \& Leach, 1967; Williams \& Miller, 1999) by incorporating an adaptive exponential smoothing parameter in the form of a logistic function of user-specified transition variables, which offers flexibility in the assignment of weight according to size $\varepsilon_{t-1}$ and magnitude $\left|\varepsilon_{t-1}\right|$ of news impact on volatility. This addresses the issue of changing characteristics of time series attributed to seasonality, trends, or structural breaks where the issue of outliers often exists. The STES method is specified as Equation 10:

$$
\begin{aligned}
& \qquad \widehat{\sigma_{t}^{2}}=\left(\alpha_{t-1}\right) \varepsilon_{t-1}^{2}+\left(1-\alpha_{t-1}\right) \widehat{\sigma_{t-1}^{2}} \\
& \text { where } \alpha_{t-1}=\frac{1}{1+\exp \left(\beta+\gamma V_{t-1}\right)}
\end{aligned}
$$

is the "adaptive or smooth transition" parameter (modelled as a logistic function), and $0<\alpha_{t-1}<1$, depending on the user-specified "transition variable" $V_{t-1}$ employed. The conditional variance in Equation 10 is a function of the calibration of the adaptive smoothing parameter $\alpha_{t-1}$ that depends on the choice of the transition variable 
$V_{t-1}$ and the optimization (using a solver) of parameters $\beta$ and $\gamma$ (coefficients of the transition variables concerned). The five different "transition variables" adopted in this study are, $\varepsilon_{t-1}^{2}$ (past squared error) denoted as STES-SE, $\varepsilon_{t-1}$ (past error) denoted as STES-E model, $\left|\varepsilon_{t-1}\right|$ (absolute past error) denoted as STES-AE model, the combination of both past error and absolute past error denoted as STES-E-AE model, and the combination of past error $\varepsilon_{t-1}$ and squared past squared error $\varepsilon_{t-1}^{2}$ denoted as STES-E-SE. If $\gamma<0$, then $\alpha_{t-1}$ will be a monotonically increasing function of the chosen transition variable $V_{t-1}$, thus increasing the impact of the squared residual (past squared shocks) and reducing the impact of variance the day before on today's conditional variance and vice versa, as indicated by Equation 6. Since exponential smoothing is not based on any statistical theory, optimization of the STES parameters $\beta$ and $\gamma$ will be by the minimization of the forecasting error defined as the subtraction of the forecast variance error $\left(\widehat{\sigma_{a}^{2}}\right)$ from the squared residual $\varepsilon_{i}^{2}$ (a proxy for actual volatility): min $\sum\left(\varepsilon_{i}^{2}-\overline{\sigma_{i}^{2}}\right)^{2}$

\subsection{Data}

The dataset comprises seven mutual fund indices of different investment objectives and risk exposure comprising Growth, Growth \& Income, Income, Balanced Growth, Balanced Growth \& Income, Balanced Income, and Mixed Asset Growth categories, which were created from the 57 individual private equity mutual funds in Malaysia (see Appendix A) sampled from January 3, 2005, to December 31, 2019. The full sample is divided into two sub-periods, one with financial crisis impact from January 3, 2005, to December 31, 2011, while the other is without financial crisis impact and runs from Jan 1, 2012, to December 31, 2019. The purpose of the analysis of the two sub-periods is to ascertain if financial crisis exerts a different impact on the volatility of mutual fund returns. The data were sourced from DATASTREAM, and the seven fund indices were created using a similar approach as adopted in generating the Dow Jones Industrial Average (DJIA) Index (Corielli \& Marcellino, 2006; Parasuraman \& Ramudu, 2014):

\section{(Mutual Fund Index under specific fund objective $)_{t}=(\text { sum of all funds } \mathrm{NAV})_{t} /$ divisor}

where $t$ denotes the period (daily in the case of this study). The divisor value of the respective fund index is obtained by dividing the summation of the net asset value (NAV) of all funds clustered within the respective fund index at a specific base date chosen by 100 . The daily fund index is then obtained by dividing the summation of the daily NAV of all funds within a cluster against the calculated divisor of the respective fund index. The daily return of each fund index is specified as:

$$
R_{t}=\ln \left[\frac{\text { Fund Index }}{\text { Fund Index }}\right]
$$


where $R_{t}$ is the compounded return of funds index derived from the first difference in logarithm form of the daily index, Fund Indext is the index on day $t$, and Fund Index $t_{t-1}$ is the index on the previous day $t$-1. Appendices B and C respectively show the daily trend and plot of the return series of the respective mutual fund indices.

The descriptive statistics of the dataset for both sub-periods are shown in Table 1 and Table 2. The mean value for all seven fund indices in both sub-periods is close to zero, indicating the mean-reverting process in the long term. The mean, maximum, and minimum in the volatile sub-period of 2005-2011 (with financial crisis impact) is consistently higher across all fund indices compared to the less volatile sub-period of 2012-2019 (without financial crisis impact). Negative skewness in all fund indices for both sub-periods indicates a higher probability of making a loss (downside risk) than making a profit. Leptokurtosis (kurtosis above 3 ) distribution was found in all fund indices across both sub-periods; but was more prominent in the sub-period with financial crisis impact, implying the existence of outliers. Significant Jarque-Bera statistics in all fund indices for both sub-periods confirmed the nonnormality of the return distribution. The augmented Dickey-Fuller statistics (see Tables 3 and 4) for all fund indices in both sub-periods are significant, implying that the data is stationary, and is therefore good for volatility estimation and forecasting.

Table -1. Descriptive statistics for sub-period with financial crisis (2005-2011).

\begin{tabular}{|c|c|c|c|c|c|c|c|c|c|}
\hline Name of Fund Index & Obs. & Mean & Max. & Min. & $\begin{array}{l}\text { Std. } \\
\text { Dev. }\end{array}$ & Skew & Kurtosis & $\begin{array}{c}\text { Jarque- } \\
\text { Bera }\end{array}$ & Prob. \\
\hline Equity Growth Fund Index & 1824 & 1.890 & 0.040 & -0.082 & 0.007 & -1.452 & 15.79 & 13067.3 & 0.00 \\
\hline $\begin{array}{l}\text { Equity Growth \& Income } \\
\text { Fund Index }\end{array}$ & 1824 & 2.490 & 0.033 & -0.074 & 0.007 & -1.341 & 15.21 & 11881.0 & 0.00 \\
\hline Equity Income Fund Index & 1824 & 1.030 & 0.033 & -0.070 & 0.007 & -1.308 & 12.59 & 7504.9 & 0.00 \\
\hline $\begin{array}{l}\text { Balanced Growth Fund } \\
\text { Index }\end{array}$ & 1824 & 0.904 & 0.031 & -0.081 & 0.007 & -2.371 & 24.71 & 37544.8 & 0.00 \\
\hline $\begin{array}{l}\text { Balanced Growth \& Income } \\
\text { Fund Index }\end{array}$ & 1824 & 0.292 & 0.025 & -0.055 & 0.005 & -1.427 & 14.41 & 10510.6 & 0.00 \\
\hline Balanced Income Fund Index & 1824 & 2.740 & 0.028 & -0.056 & 0.005 & -1.195 & 15.45 & 12206.3 & 0.00 \\
\hline $\begin{array}{l}\text { Mixed Asset Growth Fund } \\
\text { Index }\end{array}$ & 1824 & 2.190 & 0.036 & -0.066 & 0.006 & -1.821 & 19.36 & 21341.0 & 0.00 \\
\hline
\end{tabular}

Table -2. Descriptive statistics for sub-period without financial crisis (2012-2019).

\begin{tabular}{|c|c|c|c|c|c|c|c|c|c|}
\hline Name of Fund Index & Obs. & Mean & Max. & Min. & $\begin{array}{l}\text { Std. } \\
\text { Dev. }\end{array}$ & Skew & Kurtosis & $\begin{array}{c}\text { Jarque- } \\
\text { Bera }\end{array}$ & Prob. \\
\hline Equity Growth Fund Index & 2086 & 0.649 & 0.027 & -0.025 & 0.004 & -0.756 & 7.229 & 1753.0 & 0.00 \\
\hline $\begin{array}{l}\text { Equity Growth \& Income } \\
\text { Fund Index }\end{array}$ & 2086 & 0.664 & 0.024 & -0.023 & 0.004 & -0.749 & 6.719 & 1397.3 & 0.00 \\
\hline Equity Income Fund Index & 2086 & 0.322 & 0.020 & -0.028 & 0.005 & -1.191 & 7.806 & 2501.1 & 0.00 \\
\hline $\begin{array}{l}\text { Balanced Growth Fund } \\
\text { Index }\end{array}$ & 2086 & 0.046 & 0.021 & -0.028 & 0.004 & -1.820 & 14.07 & 11794.6 & 0.00 \\
\hline $\begin{array}{l}\text { Balanced Growth \& Income } \\
\text { Fund Index }\end{array}$ & 2086 & 0.064 & 0.015 & -0.017 & 0.003 & -0.855 & 6.660 & 1418.4 & 0.00 \\
\hline $\begin{array}{l}\text { Balanced Income } \quad \text { Fund } \\
\text { Index }\end{array}$ & 2086 & 1.930 & 0.018 & -0.035 & 0.004 & -0.793 & 9.312 & 3682.2 & 0.00 \\
\hline $\begin{array}{l}\text { Mixed Asset Growth Fund } \\
\text { Index }\end{array}$ & 2086 & 0.000 & 0.070 & -0.032 & 0.006 & -0.005 & 19.41 & 23408.4 & 0.00 \\
\hline
\end{tabular}

Note: Mean has been multiplied by $10^{4}$. 
Table -3. Unit root test with augmented Dickey-Fuller test for sub-period 2005-2011.

\begin{tabular}{l|c|c|c}
\hline Fund Index & ADF-stats & p-value & sig. \\
\hline Growth & -36.04 & 0.000 & $* * *$ \\
\hline Growth \& Income & -35.91 & 0.000 & $* * *$ \\
\hline Income & -36.63 & 0.000 & $* * *$ \\
\hline Balanced Growth & -38.66 & 0.000 & $* * *$ \\
\hline Balanced Growth \& Income & -37.21 & 0.000 & $* * *$ \\
\hline Balanced Income & -38.67 & 0.000 & $* * *$ \\
\hline Mixed Asset Growth & -38.45 & 0.000 & $* * *$ \\
\hline
\end{tabular}

Note: * ** and *** denote significance at the $10 \%, 5 \%$ and $1 \%$ levels, respectively.

Table -4. Unit root test with augmented Dickey-Fuller test for sub-period 2012-2019.

\begin{tabular}{l|c|c|c}
\hline Fund Index & ADF-stats & p-value & sig. \\
\hline Growth & -40.39 & 0.000 & $* * *$ \\
\hline Growth \& Income & -41.62 & 0.000 & $* * *$ \\
\hline Income & -42.02 & 0.000 & $* * *$ \\
\hline Balanced Growth & -41.87 & 0.000 & $* * *$ \\
\hline Balanced Growth \& Income & -41.03 & 0.000 & $* * *$ \\
\hline Balanced Income & -41.11 & 0.000 & $* * *$ \\
\hline Mixed Asset Growth & -42.19 & 0.000 & $* * *$ \\
\hline
\end{tabular}

Note: * ** and *** denote significance at the $10 \%, 5 \%$ and $1 \%$ levels respectively.

Table -5. Residual diagnostics of fund indices for sub-period 2005-2011.

\begin{tabular}{|c|c|c|c|c|c|c|}
\hline & \multicolumn{4}{|c|}{ Ljung-Box Q-statistics Test } & \multicolumn{2}{|c|}{ ARCH LM Test } \\
\hline & \multicolumn{4}{|c|}{ Null Hypothesis: } & \multicolumn{2}{|c|}{ Null Hypothesis: } \\
\hline & \multicolumn{4}{|c|}{ Data are independently } & \multicolumn{2}{|c|}{ ARCH effect does not exist } \\
\hline & \multicolumn{4}{|c|}{ distributed (no autocorrelation) } & & \\
\hline Fund Index & Q-stat 12) & p-value & sig. & Obs $^{*} \mathbf{R}^{2}$ & p-value & sig. \\
\hline Equity Growth & 90.75 & 0.000 & **** & 79.33 & 0.000 & **** \\
\hline Equity Growth \& Income & 84.97 & 0.000 & **** & 77.94 & 0.000 & **** \\
\hline Equity Income & 69.60 & 0.000 & **** & 66.94 & 0.000 & **** \\
\hline Balanced Growth & 32.99 & 0.001 & **** & 20.97 & 0.000 & **** \\
\hline Balanced Growth \& Income & 69.61 & 0.000 & **** & 47.94 & 0.000 & **** \\
\hline Balanced Income & 46.01 & 0.000 & **** & 68.97 & 0.000 & **** \\
\hline Mixed Asset Growth & 48.04 & 0.000 & **** & 51.96 & 0.000 & **** \\
\hline
\end{tabular}

Table -6. Residual diagnostics of fund indices for sub-period 2012-2019.

\begin{tabular}{|c|c|c|c|c|c|c|}
\hline & \multicolumn{3}{|c|}{ Ljung-Box Q-statistics Test } & \multicolumn{3}{|c|}{ ARCH LM Test } \\
\hline & \multicolumn{3}{|c|}{ Null Hypothesis: } & \multicolumn{3}{|c|}{ Null Hypothesis: } \\
\hline & \multicolumn{3}{|c|}{ Data are independently } & \multicolumn{3}{|c|}{ ARCH effect does not exist } \\
\hline & \multicolumn{3}{|c|}{ distributed (no autocorrelation) } & & & \\
\hline Fund Index & Q-stat (12) & p-value & sig. & Obs $^{*} \mathbf{R}^{2}$ & p-value & sig. \\
\hline Equity Growth & 40.29 & 0.000 & **** & 59.98 & 0.000 & **** \\
\hline Equity Growth \& Income & 28.82 & 0.004 & **** & 58.25 & 0.000 & **** \\
\hline Equity Income & 25.53 & 0.012 & **⿻丷木 & 17.07 & 0.000 & **** \\
\hline Balanced Growth & 32.98 & 0.001 & **** & 10.08 & 0.002 & **** \\
\hline Balanced Growth \& Income & 32.15 & 0.001 & **** & 57.10 & 0.000 & **** \\
\hline Balanced Income & 46.02 & 0.000 & **** & 137.72 & 0.000 & **** \\
\hline Mixed Asset Growth & 31.55 & 0.000 & *** & 6.92 & 0.009 & **** \\
\hline
\end{tabular}

Note: *, ** and *** denote significance at the $10 \%, 5 \%$ and $1 \%$ levels respectively.

The p-values of the Ljung-Box Q-Statistics are significant up to lag 12 (see Tables 5 and 6) for all seven fund indices across both sub-periods indicating the existence of autocorrelation in the return series. The Lagrange multiplier (LM) test produces observed $\mathrm{R}^{2}$ values that are all significant at a $1 \%$ significance level for all seven fund indices in both sub-periods, implying the existence of the ARCH effect. The combined results of autocorrelation up to lag 12 and the ARCH effect signifies that the GARCH model is appropriate to measure heteroskedasticity. 


\section{EMPIRICAL RESULTS AND DISCUSSIONS}

\subsection{In-Sample Estimation of GARCH Models}

Since this study focuses on forecasting volatility, it is impractical to repeatedly specify the lag order of GARCH models for each of the fund indices. As such, following Taylor (2004b), the study opted for the GARCH $(1,1)$ model specification and applied it across the standard GARCH, EGARCH, IGARCH, and GJRGARCH models. From the full sample period, there was an approximate 80:20 split between the in-sample and post-sample data running from Jan $3^{\text {rd }}, 2005$, to October $4^{\text {th }}, 2010$ (1500 observations) and Oct $5^{\text {th }}, 2010$, to Dec $30^{\text {th }}, 2011$ (324 observations), respectively. Regarding the sub-period without financial crisis, there was an approximate 70:30 split between insample and post-sample data covering Jan $3^{\text {rd }}, 2012$, to Oct $2^{\text {nd }}, 2017$ (1500 observations) and Oct $3^{\text {rd }}, 2017$, to Dec $31^{\text {st }}, 2019$ (586 observations), respectively. Parameters of the four GARCH family models were estimated under the Gaussian, Student-t, and Generalized Error Distribution (GED) innovations using the maximum likelihood estimation (MLE) method introduced by Bollerslev \& Wooldridge (1992) with the EViews legacy optimization option.

Appendices D1 to D6 provide detailed results of the parameter estimates of the 12 GARCH models for the respective fund indexes in both sub-periods. The $\beta$ coefficient values in all 12 GARCH models were consistently higher in the sub-period with financial crisis impact compared to the less volatile sub-period across all fund indices, implying a greater volatility clustering effect during a volatile period. The summation of $\alpha+\beta<1$ consistently across all fund indices implies that volatility persists over time across all indices in both sub-periods. Table 7 shows the best-fitting GARCH model. Both the EGARCH and GJR-GARCH models under non-normal error term distribution (Stud-t and GED) are the best-fitting models in both sub-periods, implying the existence of both the asymmetry effect and the leverage effect, which are well captured by both models, and concur with past studies (Alberg et al., 2008; Angabini \& Wasiuzzaman, 2011; Chuan, Mahdi, \& Kenneth, 2021; Dritsaki, 2017; Hamilton \& Susmel, 1994; Kuhe, 2018; Lim \& Sek, 2013; Musa et al., 2020; Peters, 2001; Shamiri \& Isa, 2009; Wilhelmsson, 2006).

Table -7. Best-fitting GARCH models by fund index and sub-period.

\begin{tabular}{|c|c|c|c|c|c|c|c|}
\hline & Growth & $\begin{array}{l}\text { Growth } \\
\text { Income }\end{array}$ & Income & $\begin{array}{c}\text { Bal. } \\
\text { Growth }\end{array}$ & $\begin{array}{c}\text { Bal. } \\
\text { Growth } \\
\text { Income }\end{array}$ & $\begin{array}{c}\text { Bal. } \\
\text { Income }\end{array}$ & $\begin{array}{c}\text { Mixed } \\
\text { Asset } \\
\text { Growth }\end{array}$ \\
\hline $\begin{array}{l}\text { Sub-period } \\
(2005-2011)\end{array}$ & $\begin{array}{c}\text { GJR- } \\
\text { GARCH } \\
\text { GED }\end{array}$ & $\begin{array}{c}\text { GJR- } \\
\text { GARCH } \\
\text { GED }\end{array}$ & $\begin{array}{c}\text { EGARCH } \\
\text { GED }\end{array}$ & $\begin{array}{c}\text { EGARCH } \\
\text { GED }\end{array}$ & $\begin{array}{c}\text { EGARCH } \\
\text { GED }\end{array}$ & $\begin{array}{c}\text { EGARCH } \\
\text { GED }\end{array}$ & $\begin{array}{c}\text { EGARCH } \\
\text { GED }\end{array}$ \\
\hline $\begin{array}{l}\text { Sub-period } \\
(2012-2019)\end{array}$ & $\begin{array}{c}\text { EGARCH } \\
\text { GED }\end{array}$ & $\begin{array}{c}\text { EGARCH- } \\
\text { Stud T }\end{array}$ & $\begin{array}{c}\text { EGARCH } \\
\text { GED }\end{array}$ & $\begin{array}{c}\text { EGARCH } \\
\text { GED }\end{array}$ & $\begin{array}{c}\text { EGARCH } \\
\text { GED }\end{array}$ & $\begin{array}{c}\text { EGARCH } \\
\text { GED }\end{array}$ & $\begin{array}{c}\text { EGARCH- } \\
\text { Stud T }\end{array}$ \\
\hline
\end{tabular}

The residual diagnostic test (details available upon request) revealed insignificant p-values of the F-statistics and chi-squares in the ARCH LM test, as well as insignificant p-values of the Ljung-Box $\mathrm{Q}^{2}$ statistics, implying that all information related to volatility has been well captured by the estimated models, and are therefore appropriate for volatility forecasting.

\subsection{Post-Sample Forecasting Evaluation}

Two criteria, MAE (mean absolute error) and RMSE (root mean square error), were employed to evaluate and determine the best post-sample one-day-ahead volatility forecasting model for the fund indices specified as: 
$\operatorname{RMSE}=\sqrt{\frac{1}{N} \sum_{t=0}^{N}\left(v_{t}-\widehat{v_{t}}\right)^{2}}$

$\operatorname{MAE}=\frac{1}{N} \sum_{t=1}^{N}\left|v_{t}-\widehat{v_{t}}\right|$

where the squared residual $\varepsilon_{t}^{2}$ is used as a proxy for actual volatility denoted by $v_{t}, \widehat{v_{t}}$ is the forecast variance of the model concerned, and $N$ denotes post-sample observations. The forecast variance of all 22 models and methods examined were compared against the squared residual to obtain forecast errors evaluated by both MAE and RMSE loss functions. Smaller MAE and RMSE denote a better model. Theil-U statistics were used for the relative performance of the models across each fund index, where the MAE and RMSE values of each model in a fund index were compared against the benchmark GJRGARCH-t model. The smallest value of the mean Theil-U is obtained by averaging the Theil- $\mathrm{U}$ values of each model across fund indices. The best performing model across the fund index is indicated by the lowest mean Theil-U value (ranked 1) to the poorest performing model with the highest mean Theil-U value (ranked 22) (see Appendices E1 to E4 for details). Table 8 summarizes the top five and bottom five ranked models/methods in terms of post-sample volatility forecasting performance.

Table -8. Post-sample volatility forecasting ranking of models.

\begin{tabular}{|c|c|c|c|c|c|}
\hline & & \multicolumn{2}{|c|}{ Sub-period 2005-2011 } & \multicolumn{2}{|c|}{ Sub-period 2012-2019 } \\
\hline & & MAE & RMSE & MAE & RMSE \\
\hline & Rank & Model / method & Model / method & Model / method & Model / method \\
\hline Top 5 ranked & 1 & STES-E \& AE & STES-E \& AE & STES-E \& AE & EGARCH-t \\
\hline $\begin{array}{c}\text { (in descending } \\
\text { order) }\end{array}$ & 2 & STES-AE & IGARCH-N & STES-AE & GARCH-t \\
\hline & 3 & $\begin{array}{c}\text { EWMA- } \\
\text { Riskmetric }\end{array}$ & STES-AE & Naïve Variance & STES-AE \\
\hline & 4 & STES-SE & $\begin{array}{c}\text { EWMA- } \\
\text { Riskmetric }\end{array}$ & EGARCH-t & STES-E \& AE \\
\hline & 5 & IGARCH-N & STES-ESE & GARCH-N & GJRGARCH-t \\
\hline $\begin{array}{c}\text { Bottom } 5 \\
\text { ranked }\end{array}$ & 18 & GARCH-t & $\begin{array}{c}\text { GJRGARCH- } \\
\text { GED }\end{array}$ & MA30 & GJRGARCH-N \\
\hline $\begin{array}{c}\text { (in descending } \\
\text { order) }\end{array}$ & 19 & EGARCH-t & GARCH-t & EGARCH-GED & EGARCH-GED \\
\hline & 20 & GJRGARCH-t & GJRGARCH-t & GARCH-GED & GARCH-GED \\
\hline & 21 & RW & Naïve Variance & $\begin{array}{c}\text { GJRGARCH- } \\
\text { GED }\end{array}$ & $\begin{array}{c}\text { GJRGARCH- } \\
\text { GED }\end{array}$ \\
\hline & 22 & Naïve Variance & RW & RW & RW \\
\hline
\end{tabular}

Under MAE criteria, STES-E\&AE emerged as the best model for post-sample volatility forecasting both subperiods (see Table 8), followed by the STES-AE method. However, STES-AE is ranked third under the RMSE criteria in both sub-periods. The RW method was the worst-performing model and ranked last in both sub-periods, hence invalidating the Random Walk Theory, which claims that successive price movements are not correlated and random.

The model confidence set (MCS) of Hansen et al. (2011) was applied for a robustness check of the post-sample results. Unlike RMSE and MAE criteria, which aim to determine the "best post-sample forecasting model" based on a benchmark model (which is rather subjective), the MCS procedure, focuses on examining "equal predictive ability" among models that yields a set of remaining (surviving) models known as the model confidence set (MCS) through 
a sequential bootstrap elimination process. Table 9 summarizes the results of the MCS procedure (detailed MCS results are not presented here). Using the squared forecast error (SE), the MCS result is rather homogenous in the 2012-2019 sub-period where the EGARCH-GED model obtained a better mean ranking than the STES methods. However, when using the absolute forecast error (AE), the STES methods, especially the STES-E\&AE method, were the least eliminated models with the best mean ranking across all fund indices in both sub-periods.

Table -9. MCS procedure results.

\begin{tabular}{|c|c|c|c|c|c|c|c|c|}
\hline \multirow[b]{3}{*}{ Model / Method } & \multicolumn{4}{|c|}{ Sub-period 2005-2011 } & \multicolumn{4}{|c|}{ Sub-period 2012-2019 } \\
\hline & \multicolumn{2}{|c|}{ Absolute Error } & \multicolumn{2}{|c|}{ Squared Error } & \multicolumn{2}{|c|}{ Absolute Error } & \multicolumn{2}{|c|}{ Squared Error } \\
\hline & Count & Mean Rank & Count & Mean Rank & Count & Mean Rank & Count & Mean Rank \\
\hline RW & 1 & 15.0 & 1 & 22.0 & $\mathrm{O}$ & & & \\
\hline Naïve & 2 & 20.0 & 5 & 20.6 & 7 & 10.7 & 7 & 19.3 \\
\hline EWMA-OP & 7 & 6.1 & 7 & 7.3 & 6 & 13.2 & 7 & 12.3 \\
\hline EWMA-RM & 7 & 4.9 & 7 & 10.0 & 6 & 15.3 & 6 & 15.5 \\
\hline MA30 & 7 & 8.9 & 7 & 16.9 & 7 & 17.9 & 5 & 20.4 \\
\hline GARCH-N & 2 & 16.0 & 7 & 13.6 & 7 & 8.1 & 7 & 7.1 \\
\hline GJRGARCH-N & 2 & 15.5 & 7 & 12.7 & 6 & 10.3 & 6 & 8.3 \\
\hline IGARCH-N & 7 & 7.6 & 7 & 7.3 & 6 & 13.8 & 7 & 14.6 \\
\hline EGARCH-N & 3 & 14.3 & 7 & 12.3 & 7 & 9.9 & 7 & 4.0 \\
\hline GARCH-t & 2 & 15.5 & 6 & 16.3 & 7 & 11.3 & 7 & 10.9 \\
\hline GJRGARCH-t & 3 & 18.0 & 6 & 16.3 & 7 & 13.0 & 7 & 10.6 \\
\hline IGARCH-t & 6 & 6.5 & 6 & 8.8 & 6 & 14.5 & 7 & 15.3 \\
\hline EGARCH-t & 2 & 13.0 & 6 & 13.2 & 7 & 10.0 & 7 & 5.0 \\
\hline GARCH-GED & 3 & 15.0 & 6 & 11.0 & 7 & 5.4 & 7 & 7.7 \\
\hline GJRGARCH-GED & 3 & 15.7 & 6 & 11.7 & 7 & 8.9 & 7 & 9.1 \\
\hline IGARCH-GED & 6 & 7.7 & 6 & 7.8 & 6 & 13.2 & 7 & 15.3 \\
\hline EGARCH-GED & 3 & 13.3 & 6 & 10.8 & 7 & 7.7 & 7 & 3.3 \\
\hline STES-SE & 7 & 5.3 & 7 & 7.4 & 6 & 11.3 & 7 & 11.6 \\
\hline STES-E & 7 & 7.3 & 7 & 5.9 & 6 & 13.0 & 7 & 11.9 \\
\hline STES-AE & 7 & 3.0 & 7 & 8.1 & 6 & 3.2 & 7 & 9.0 \\
\hline STES-EAE & 7 & 1.0 & 7 & 3.0 & 7 & 1.9 & 7 & 10.1 \\
\hline STES-ESE & 7 & 8.1 & 7 & 4.7 & 6 & 10.5 & 7 & 9.6 \\
\hline
\end{tabular}

Note: Mean rank is calculated from average of ranking scored by each fund index based on the p-value, significance at $15 \%$ level form MCS procedure. Count refers to remaining number of models/methods that remain uneliminated in the model confidence set after MCS procedure.

\subsection{Discussion on Results}

The STES method with the error (sign of previous period's shock) and absolute error (the size of previous period's shock) as transition variables emerged as the best one-day-ahead volatility forecasting method regardless of volatility condition. This implies that the STES-E\&AE method has well-captured the volatility of the fund indices attributed to both sign (positive or negative) and size (magnitude) of the previous period's shock. The results support the superiority of the STES methods, as revealed by findings of Taylor (2004a), Taylor (2004b), and Liu et al. (2020). The strength and robustness of the STES methods are attributed to "their adaptive time-varying smoothing parameter" the form of a logistic function of user-specified transition variables, where the value of this parameter reduces to exert lower weight to the outlying observation (Liu et al., 2020).

It was shown that the five STES methods examined ranked higher than most GARCH models in both subperiods (see Appendices E1 to E4), regardless of post-sample forecasting performance evaluation criteria. Although the EGARCH-t is the best post-sample model under RMSE criteria in the sub-period without financial crisis impact, the result is debatable. The reason being, that RMSE criteria tend to result in spurious inferences, particularly in the presence of outliers due to the nature of RMSE's quadratic function when a higher weight is assigned to a larger forecast error (Franses \& Ghijsels, 1999). The results thus refuted the claim of GARCH's superiority in post-sample volatility forecasting by Hansen \& Lunde (2005). The results have empirically proven 
the overall superiority of STES methods over the GARCH models in forecasting the volatility of mutual funds' returns. With this, the null hypotheses are rejected, or both alternative hypotheses, $\mathrm{H}_{1 \mathrm{~A}}$ and $\mathrm{H}_{1 \mathrm{~B}}$, are supported.

\section{CONCLUSION}

This study examines the post-sample volatility forecasting performance of 22 models, aimed at verifying if the STES method can outperform the well-known GARCH family models. The results provide further evidence on the robustness and supremacy of the STES method in volatility forecasting, which was applied to seven mutual fund indices (created from 57 individual mutual funds' daily net asset values of different investment objectives and risk characteristics in Malaysia) for two different sub-periods, with financial crisis impact (2005-2011) and without financial crisis impact (2012-2019). The results revealed that the STES methods, particularly with error and absolute error as transition variables, provide the best one-day-ahead volatility forecasting across seven mutual fund indices in both sub-periods. The output from the applied MCS procedure reaffirmed the robustness of the results from both the MAE and RMSE evaluation criteria.

Although the asymmetric EGARCH and GJRGARCH under non-normal error term distribution assumptions have been effective in captured asymmetric and leverage effects, the post-sample forecasting performance was otherwise. It can be concluded that GARCH models with good in-sample estimation need not necessarily be a good model for post-sample volatility forecasting particularly during a volatile period where the issue of outliers is prominent. This study has provided strong empirical evidence of the supremacy of STES method, STES-E\&AE particularly, over well-known GARCH models in one-day ahead volatility forecasting of private equity mutual funds' return in the Malaysian case, regardless of market volatility condition.

This study has expanded the literature on financial volatility through the application of STES methods to measure the volatility of mutual funds' returns, which to our best knowledge has never been examined in prior mutual fund studies. The STES method provides an empirical method for investing community (retail and institutional investors) to better manage the investment risk of mutual funds and can even be applied for the microanalysis of individual mutual funds' volatility. Though the study is confined to private equity mutual funds in Malaysia, the creation of the seven equity-based mutual fund indices is a notable contribution of this study, which, to the best of our knowledge, has never existed in Malaysia. It is hoped that the indices created in this study will inspire the generation of other sectorial or regional mutual fund indices to enable a more diversified macroanalysis. The inclusion of daily mutual fund flows as a transition variable in the STES method is suggested for future volatility studies.

Funding: This study received no specific financial support.

Competing Interests: The authors declare that they have no competing interests.

Acknowledgement: All authors contributed equally to the conception and design of the study.

\section{REFERENCES}

Alberg, D., Shalit, H., \& Yosef, R. (2008). Estimating stock market volatility using asymmetric GARCH models. Applied Financial Economics, 18(15), 1201-1208. Available at: https://doi.org/10.1080/09603100701604225.

Angabini, A., \& Wasiuzzaman, S. (2011). GARCH Models and financial crisis -A case study of the Malaysian stock market. The International Journal of Applied Economics and Finance, 5(3), 226-236. Available at: https://doi.org/10.3923/ijaef.2011.226.236.

Annuar, M., Shamsher, M., \& Ngu, M. H. (1997). Selectivity and timing: Evidence from the performance of Malaysian unit trusts. Pertanika Journal of Social Science and Humanities, 5(1), 45-57.

Bollerslev, T. (1986). Generalized autoregressive conditional heteroskedasticity. Journal of Econometrics, 31(3), 307-327. Available at: https://doi.org/10.1016/0304-4076(86)90063-1. 
Bollerslev, T., Chou, R. Y., \& Kroner, K. F. (1992). ARCH modeling in finance: A review of the theory and empirical evidence. Journal of Econometrics, 52(1-2), 5-59.

Bollerslev, T., \& Engle, R. F. (1993). Common persistence in conditional variances. Econometrica, 61(1), 167-186. Available at: https://doi.org/10.2307/2951782.

Bollerslev, T., \& Wooldridge, J. M. (1992). Quasi-maximum likelihood estimation and inference in dynamic models with timevarying covariances. Econometric Reviews, 11 (2), 143-172. Available at: https://doi.org/10.1080/07474939208800229.

Busse, J. A. (1999). Volatility timing in mutual funds: Evidence from daily returns. The Review of Financial Studies, 12(5), 10091041. Available at: https://doi.org/10.1093/rfs/12.5.1009.

Carnero, M. A., Peña, D., \& Ruiz, E. (2012). Estimating GARCH volatility in the presence of outliers. Economics Letters, 114(1), 86-90. Available at: https://doi.org/10.1016/j.econlet.2011.09.023.

Chen, L.-W., Adams, A., \& Taffler, R. (2013). What style-timing skills do mutual fund "stars" possess? Journal of Empirical Finance, 21, 156-173. Available at: https://doi.org/10.1016/j.jempfin.2013.01.004.

Chong, C. W., Ahmad, M. I., \& Abdullah, M. Y. (1999). Performance of GARCH models in forecasting stock market volatility. Journal of Forecasting, 18(5), 333-343. Available at: https://doi.org/10.1002/(sici)1099-131x(199909)18:5\%3C333::aidfor742\%3E3.0.co;2-k.

Chou, R. (1988). Volatility persistence and stock valuations: Some empirical evidence using garch. Journal of Applied Econometrics, 3(4), 279-294. Available at: https://doi.org/10.1002/jae.3950030404.

Choudhry, T. (1995). Integrated-GARCH and non-stationary variances: Evidence from European stock markets during the 1920s and 1930s. Economics Letters, 48(1), 55-59. Available at: https://doi.org/10.1016/0165-1765(94)00583-n.

Chuan, J. N., Mahdi, S., \& Kenneth, R. (2021). The impact of covid-19 pandemic on stock market return volatility: Evidence from Malaysia and Singapore. Asian Economic and Financial Reviere, 11(3), 191-204. Available at: https://doi.org/10.18488/journal.aefr.2021.113.191.204.

Chuang, I.-Y., Lu, J.-R., \& Lee, P.-H. (2007). Forecasting volatility in the financial markets: A comparison of alternative distributional assumptions. Applied Financial Economics, 17(13), 1051-1060. Available at: https://doi.org/10.1080/09603100600771000.

Corielli, F., \& Marcellino, M. (2006). Factor based index tracking. Journal of Banking \& Finance, 30(8), 2215-2233. Available at: https://doi.org/10.1016/j.jbankfin.2005.07.012.

DiBartolomeo, D., \& Witkowski, E. R. (1997). Mutual fund misclassification: Evidence based on style analysis. Financial Analysts Journal, 53(5), 32-43. Available at: https://doi.org/10.2469/faj.v53.n5.2115.

Dritsaki, C. (2017). An empirical evaluation in GARCH volatility modeling: Evidence from the Stockholm stock exchange. Journal of Mathematical Finance, 7(2), 366-390. Available at: https://doi.org/10.4236/jmf.2017.72020.

Engle, R. F. (1982). Autoregressive conditional heteroscedasticity with estimates of the variance of United Kingdom inflation. Econometrica, 50(4), 987-1007. Available at: https://doi.org/10.2307/1912773.

Engle, R. F., \& Ng, V. K. (1993). Measuring and testing the impact of news on volatility. The Journal of Finance, 48(5), 17491778. Available at: https://doi.org/10.1111/j.1540-6261.1993.tb05127.x.

Engle, R. F., \& Bollerslev, T. (1986). Modelling the persistence of conditional variances. Econometric Reviews, 5(1), 1-50. Available at: https://doi.org/10.1080/07474938608800095.

Figlewski, S. (1997). Forecasting volatility. Financial Markets, Institutions \& Instruments, 6(1), 1-88.

Franses, P. H., \& Ghijsels, H. (1999). Additive outliers, GARCH and forecasting volatility. International Journal of Forecasting, 15(1), 1-9. Available at: https://doi.org/10.1016/s0169-2070(98)00053-3.

Glosten, L. R., Jagannathan, R., \& Runkle, D. E. (1993). On the relation between the expected value and the volatility of the nominal excess return on stocks. The Journal of Finance, 48(5), 1779-1801. Available at: https://doi.org/10.1111/j.1540-6261.1993.tb05128.x.

Grané, A., \& Veiga, H. (2014). Outliers, GARCH-type models and risk measures: A comparison of several approaches. Journal of Empirical Finance, 26, 26-40. Available at: https://doi.org/10.1016/j.jempfin.2014.01.005. 
Hamilton, J. D., \& Susmel, R. (1994). Autoregressive conditional heteroskedasticity and changes in regime. Journal of Econometrics, 64(1-2), 307-333. Available at: https://doi.org/10.1016/0304-4076(94)90067-1.

Hansen, P. R., \& Lunde, A. (2005). A forecast comparison of volatility models: Does anything beat a GARCH $(1,1)$ ? Journal of Applied Econometrics, 20(7), 873-889. Available at: https://doi.org/10.1002/jae.800.

Hansen, P. R., Lunde, A., \& Nason, J. M. (2011). The model confidence set. Econometrica, 79(2), 453-497. Available at: https://doi.org/10.3982/ecta5771.

Haroon, R. S., Sadaqat, M., Jebran, K., \& Ali Memon, Z. (2018). Size premium, value premium and market timing: Evidence from an emerging economy. Journal of Economics, Finance and Administrative Science, 23(46), 266-288. Available at: https://doi.org/10.1108/jefas-09-2017-0090.

Hossain, M. J., Akter, S., \& Ismail, M. T. (2021). Performance analysis of GARCH family models in three time-frames. Malaysian Economic Journal, 55(2), 15-28. Available at: https://doi.org/10.17576/jem-202 1-5502-2.

Jin, X.-J., \& Yang, X.-l. (2004). Empirical study on mutual fund objective classification. Journal of Zhejiang University-Science A, 5(5), 533-538. Available at: https://doi.org/10.1631/jzus.2004.0533.

Kim, M., Shukla, R., \& Tomas, M. (2000). Mutual fund objective misclassification. Journal of Economics and Business, 52(4), 309323. Available at: https://doi.org/10.1016/s0148-6195(00)00022-9.

Kuhe, D. A. (2018). Modeling volatility persistence and asymmetry with exogenous breaks in the Nigerian stock returns. $C B N$ Journal of Applied Statistics, 9(1), 167-196.

Lim, C. M., \& Sek, S. K. (2013). Comparing the performances of GARCH-type models in capturing the stock market volatility in Malaysia. Procedia Economics and Finance, 5, 478-487. Available at: https://doi.org/10.1016/s22 12-5671(13)00056-7.

Liu, M., Taylor, J. W., \& Choo, W.-C. (2020). Further empirical evidence on the forecasting of volatility with smooth transition exponential smoothing. Economic Modelling, 93, 651-659. Available at: https://doi.org/10.1016/j.econmod.2020.02.021.

Luo, L., Pairote, S., \& Chatpatanasiri, R. (2017). GARCH-type forecasting models for volatility of stock market and MCS test. Communications in Statistics-Simulation and Computation, 46(7), 5303-5312. Available at: https://doi.org/10.1080/03610918.2016.1152366.

Mabrouk, S. (2017). Volatility modelling and parametric value-at-risk forecast accuracy: evidence from metal products. Asian Economic and Financial Review, 7(1), 63-80. Available at: https://doi.org/10.18488/journal.aefr/2017.7.1/102.1.63.80.

Mandelbrot, B. (1963). The variation of certain speculative prices. Journal of Business, 36(4), 394-419. Available at: https://doi.org/10.1086/294632.

Mohamad, S., \& Nassir, A. M. (1995). The performance of unit trusts in Malaysia: Some evidence. Capital Markets Review, 3(2), 51-69.

Musa, Y., Adamu, I., \& Dauran, N. S. (2020). Forecasting of the Nigeria stock returns volatility using GARCH models with structural breaks. Asian Research Journal of Mathematics, 16(2), 39-50. Available at: https://doi.org/10.9734/arjom/2020/v16i230174.

Nelson, D. B. (1991). Conditional heteroskedasticity in asset returns: A new approach. Econometrica, 59(2), 347-370. Available at: https://doi.org/10.2307/2938260.

Parasuraman, N. R., \& Ramudu, P. J. (2014). Price weighted Vs. Value weighted index: A comparative analysis and impact on index based portfolio performance. Working Paper. Alliance University, Bangalore, India.

Peters, J. (2001). Estimating and forecasting volatility of stock indices using asymmetric GARCH models and (Skewed) studentt densities. Working Paper. Universite de Liege, Belgium.

Poon, S.-H., \& Granger, C. W. J. (2003). Forecasting volatility in financial markets: A review. Journal of Economic Literature, $41(6), 478-539$.

Rana, S. B. (2020). Dynamics of time varying volatility in stock returns: Evidence from Nepal stock exchange. Journal of Business and Social Sciences Research, 5(1), 15-34. Available at: https://doi.org/10.3126/jbssr.v5i1.30196. 
Shamiri, A., \& Isa, Z. (2009). Modeling and forecasting volatility of the Malaysian stock markets. Journal of Mathematics and Statistics, 5(3), 234-240. Available at: https://doi.org/10.3844/jmssp.2009.234.240.

Tang, K., Wang, W., \& Xu, R. (2012). Size and performance of Chinese mutual funds: The role of economy of scale and liquidity. Pacific-Basin Finance Journal, 20(2), 228-246. Available at: https://doi.org/10.1016/j.pacfin.201 1.09.002.

Taylor, J. W. (2004a). Smooth transition exponential smoothing. Journal of Forecasting, 23(6), 385-404.

Taylor, J. W. (2004b). Volatility forecasting with smooth transition exponential smoothing. International Journal of Forecasting, 20(2), 273-286. Available at: https://doi.org/10.1016/j.ijforecast.2003.09.010.

Trigg, D., \& Leach, A. (1967). Exponential smoothing with an adaptive response rate. Journal of the Operational Research Society, 18(1), 53-59. Available at: https://doi.org/10.2307/3010768.

Vieira, E. S., Neto, N. M. V., \& Da Mota, J. F. S. S. (2017). Do Portuguese mutual funds display forecasting skills?: A study on selectivity and market timing ability. Language, 34(4), 597-631. Available at: https://doi.org/10.1 108/sef-09-20150233.

Wilhelmsson, A. (2006). GARCH forecasting performance under different distribution assumptions. Journal of Forecasting, 25(8), 561-578. Available at: https://doi.org/10.1002/for.1009.

Williams, D. W., \& Miller, D. (1999). Level-adjusted exponential smoothing for modeling planned discontinuities. International Journal of Forecasting, 15(3), 273-289. Available at: https://doi.org/10.1016/s0169-2070(98)00083-1.

Xie, S., \& Huang, X. (2013). An empirical analysis of the volatility in the open-end fund market: Evidence from China. Emerging Markets Finance and Trade, 49(sup4), 150-162. Available at: https://doi.org/10.2753/ree1540-496x4905s411. 
Appendix -A. List of 57 equity-based mutual funds.

\begin{tabular}{|c|c|c|c|}
\hline Fund category & Name of Fund & Fund Management & Fund Inception \\
\hline \multirow[t]{33}{*}{ Growth } & Public Aggressive Growth Fund & Public Mutual Bhd & 25th Apr 1995 \\
\hline & Public Equity Fund & Public Mutual Bhd & 15 th Aug 2001 \\
\hline & Public Focus Select Fund & Public Mutual Bhd & 25 th Nov 2004 \\
\hline & Public Growth Fund & Public Mutual Bhd & 11 th Dec 1984 \\
\hline & Public Index Fund & Public Mutual Bhd & 2nd Mar 1992 \\
\hline & Public Industry Growth Fund & Public Mutual Bhd & 18th Nov 1993 \\
\hline & Public Islamic Equity Fund & Public Mutual Bhd & 28th May 2003 \\
\hline & Public Ittikal Fund & Public Mutual Bhd & 10th Apr 1997 \\
\hline & Public SmallCap Fund & Public Mutual Bhd & 13th Jun 2000 \\
\hline & PB Growth & Public Bank Bhd & 3rd Oct 2002 \\
\hline & Principal DALI Equity Fund & Principal & 30th Apr 2003 \\
\hline & Principal DALI Equity Growth Fund & Principal & 7th May 1998 \\
\hline & Principal Islamic Enhanced Opportunities Fund & Principal & 15 th June 1995 \\
\hline & Principal Islamic SmallCap Opportunities Fund & Principal & 30th Apr 2003 \\
\hline & Principal Malaysia Enhanced Opportunities Fund & Principal & 18th Aug 2004 \\
\hline & Principal Malaysia Opportunities Fund & Principal & 12th Mar 1998 \\
\hline & Principal Malaysia Titans Plus Fund & Principal & 28th Sep 1998 \\
\hline & Principal DALI Asia Pacific Equity Growth Fund & Principal & 8 th Oct 2004 \\
\hline & Principal KLCI-Linked Fund & Principal & 8th Jun 2000 \\
\hline & AmIttikal Fund & AmInvest Bhd & 12th Jan 1993 \\
\hline & Am Cumulative Growth Fund & AmInvest Bhd & 24th Jul 1996 \\
\hline & Am Malaysia Equity Fund & AmInvest Bhd & 15 th Oct 2001 \\
\hline & Affin Hwang Aiiman Growth Fund & AffinHwang Asset & 8 th Oct 2002 \\
\hline & Affin Hwang Select Asia (ex-Japan) Quantum Fund & AffinHwang Asset & 15th Apr 2004 \\
\hline & Affin Hwang Select Opportunities Fund & AffinHwang Asset & 7 th Sep 2001 \\
\hline & Manulife Investment Equity Index Fund & Manulife Investment & 26th Jun 1997 \\
\hline & Manulife Investment Value Fund & Manulife Investment & 28th Jul 1995 \\
\hline & Manulife Investment Regular Savings Fund & Manulife Investment & 29th Sep 2004 \\
\hline & Manilife Dana Ekuiti Dinamik Fund & Manulife Investment & 6th Oct 2003 \\
\hline & Manulife Equity Fund & Manulife Investment & 10th Jul 2000 \\
\hline & Eastspring Investment Growth Fund & Eastspring Investment & 29th May 2001 \\
\hline & Eastspring Investment SmallCap Fund & Eastspring Investment & 29th May 2001 \\
\hline & Eastspring Investment Dana Al-Ilham Fund & Eastspring Investment & 14th Aug 2002 \\
\hline \multirow[t]{6}{*}{ Growth \& Income } & Public Regular Savings Fund & Public Mutual Bhd & 25th Apr 1994 \\
\hline & Public Savings Fund & Public Mutual Bhd & 29th Mar 1981 \\
\hline & Principal Titans Growth \& Income Fund & Principal & 15th May 1991 \\
\hline & AM Total Return Fund & AmInvest Bhd & 10th Jan 1989 \\
\hline & Affin Hwang Equity Fund & AffinHwang Asset & 29th Apr 1993 \\
\hline & Manulife Managed Fund & Manulife Investment & 10th Jul 2000 \\
\hline \multirow[t]{3}{*}{ Income } & Principal Titans Income Plus Fund & Principal & 1st Oct 2003 \\
\hline & Manulife Investment Syariah Index Fund & Manulife Investment & 26th Jan 2002 \\
\hline & Eastspring Equity Income Fund & Eastspring Investment & 18th Oct 2004 \\
\hline \multirow[t]{2}{*}{ Balanced Growth } & Principal Islamic Lifetime Balanced Growth Fund & Principal & 26th May 2003 \\
\hline & Principal Lifetime Balanced Fund & Principal & 12th Mar 1998 \\
\hline \multirow[t]{9}{*}{$\begin{array}{l}\text { Balanced Growth \& } \\
\text { Income }\end{array}$} & Public Balanced Fund & Public Mutual Bhd & 7th Jun 1995 \\
\hline & PB Balanced Fund & Public Bank Bhd & 5th May 1998 \\
\hline & Principal Islamic Lifetime Balanced & Principal & 8 th Mar 2001 \\
\hline & Principal Lifetime Balanced Income Fund & Principal & 10th Aug 1995 \\
\hline & Principal Dynamic Enhanced Malaysia Income Fund & Principal & 12th Mar 1998 \\
\hline & Affin Hwang Aiiman Balanced Fund & AffinHwang Asset & 11 th Nov 2001 \\
\hline & Affin Hwang Select Balanced Fund & AffinHwang Asset & 28th Jul 2003 \\
\hline & Manulife Investment Balanced Fund & Manulife Investment & 2nd Jun 1991 \\
\hline & Eastspring Investment Balanced Fund & Eastspring Investment & 29th May 2001 \\
\hline \multirow[t]{2}{*}{ Balanced Income } & Am Balanced Fund & AmInvest Bhd & 16th Sep 2003 \\
\hline & Am Islamic Balanced Fund & AmInvest Bhd & 10th Sep 2004 \\
\hline \multirow[t]{2}{*}{ Mixed Asset Growth } & Eastspring Investment Dana Dinamik Fund & Eastspring Investment & 25th Feb 2004 \\
\hline & Eastspring Investment Dynamic Fund & Eastspring Investment & 6th Nov 2003 \\
\hline
\end{tabular}



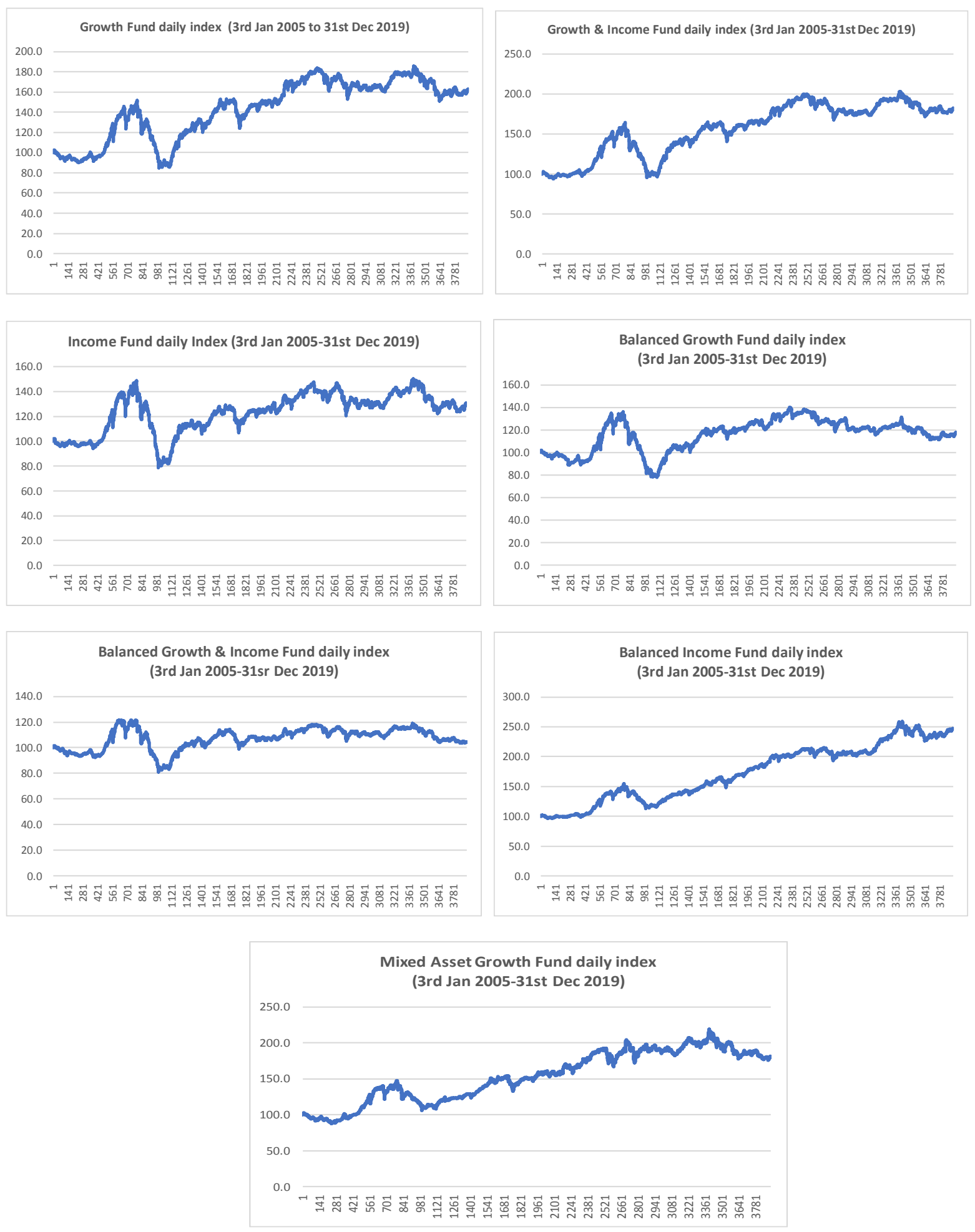

Appendix -B. Daily index of seven equity private mutual fund indices. 
Equity Growth Fund Index - Log Return (2005-2019)

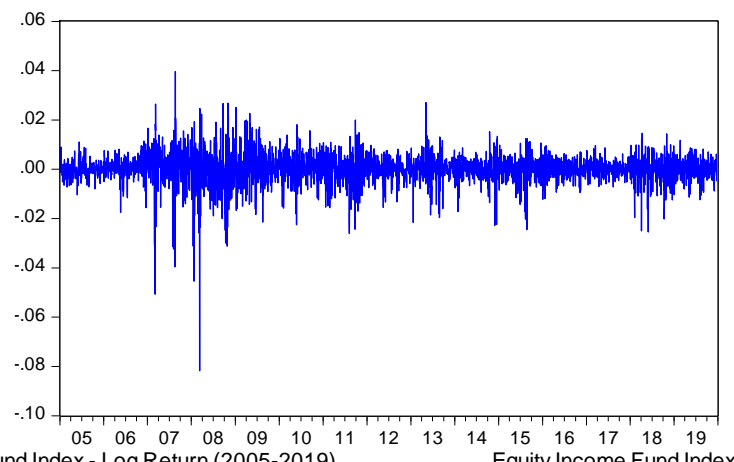

Equity Growth \& Income Fund Index - Log Return (2005-2019)

Equity Income Fund Index - Log Return (2005-2019)


Appendix -C. Plot of daily return series for all seven fund indices (2005-2019). 
Appendix -D1. Parameter estimates under Gaussian distribution for sub-period with financial crisis (2005-2011).

\begin{tabular}{|c|c|c|c|c|c|c|c|c|c|c|c|c|c|c|c|}
\hline Model & $\begin{array}{c}\text { Parameters \& } \\
\text { Goodness of } \\
\text { Fit Criteria }\end{array}$ & $\begin{array}{c}\text { Growth } \\
\text { Fund } \\
\text { Index }\end{array}$ & & $\begin{array}{l}\text { Growth \& } \\
\text { Income } \\
\text { Fund } \\
\text { Index }\end{array}$ & & $\begin{array}{l}\text { Income } \\
\text { Fund } \\
\text { Index }\end{array}$ & & $\begin{array}{c}\text { Bal. } \\
\text { Growth } \\
\text { Fund } \\
\text { Index }\end{array}$ & & $\begin{array}{c}\text { Bal. } \\
\text { Growth \& } \\
\text { Income } \\
\text { Fund Index }\end{array}$ & & $\begin{array}{l}\text { Bal. } \\
\text { Income } \\
\text { Fund } \\
\text { Index }\end{array}$ & & $\begin{array}{c}\text { Mixed } \\
\text { Asset } \\
\text { Growth } \\
\text { Fund } \\
\text { Index }\end{array}$ & \\
\hline \multirow[t]{6}{*}{ GARCH-N } & $\omega_{0}\left(\begin{array}{lll}x & 10^{-6}\end{array}\right)$ & 0.437 & ***** & 0.434 & ******* & 0.392 & ***** & 1.640 & ****** & 0.269 & **** & 0.472 & ***** & 1.200 & **** \\
\hline & $\alpha_{\mathrm{i}}$ & 0.160 & ****** & 0.133 & 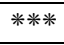 & 0.123 & ****** & 0.094 & ******* & 0.120 & **** & 0.120 & ***** & 0.189 & ***** \\
\hline & $\beta_{j}$ & 0.850 & ***** & 0.869 & 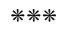 & 0.882 & ***** & 0.884 & **⿻丷木大 & 0.882 & ***** & 0.866 & 米米米 & 0.799 & 米米 \\
\hline & AIC & -7.407 & & -7.564 & & -7.380 & & -7.256 & & -8.017 & & -8.098 & & -7.764 & \\
\hline & BIC & $\begin{array}{l}-7.396 \\
\end{array}$ & & -7.553 & & -7.369 & & -7.246 & & -8.006 & & -8.087 & & -7.754 & \\
\hline & $\log \mathrm{L}$ & 5562 & & 5680 & & 5538 & & 5445 & & 6016 & & 6076 & & 5826 & \\
\hline \multirow[t]{7}{*}{ EGARCH-N } & $\omega_{0}\left(\begin{array}{lll}x & 10^{-6}\end{array}\right.$ & -0.461 & ******* & -0.408 & ******** & -0.322 & ****** & -0.214 & ******** & -0.363 & **** & -0.451 & 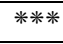 & -0.761 & ***** \\
\hline & $\alpha_{\mathrm{i}}$ & 0.281 & ***** & 0.232 & ****** & 0.226 & ***** & 0.079 & ****** & 0.204 & **** & 0.212 & ***** & 0.320 & **** \\
\hline & $\beta_{\mathrm{j}}$ & 0.975 & ***** & 0.977 & **⿻丷木⺕ & 0.984 & **** & 0.984 & **⿻丷木大 & 0.980 & ***** & 0.973 & ***** & 0.949 & ***** \\
\hline & $\gamma_{\mathrm{i}}$ & -0.046 & ***** & -0.050 & ***** & -0.035 & ***** & -0.036 & ****** & -0.046 & **** & -0.045 & ***** & -0.030 & 米* \\
\hline & AIC & -7.404 & & -7.560 & & -7.391 & & -7.279 & & -8.033 & & -8.102 & & -7.765 & \\
\hline & $\mathrm{BIC}$ & -7.389 & & -7.546 & & -7.376 & & -7.265 & & -8.018 & & -8.087 & & -7.751 & \\
\hline & $\log \mathrm{L}$ & 5560 & & 5678 & & 5547 & & 5463 & & 6028 & & 6080 & & 5828 & \\
\hline \multirow[t]{5}{*}{ IGARCH-N } & $\alpha_{\mathrm{i}}$ & 0.100 & ***** & 0.081 & ***** & 0.073 & **** & 0.010 & ***** & 0.070 & ***** & 0.060 & 米米 & 0.110 & **** \\
\hline & $\beta_{\mathrm{j}}$ & 0.900 & ***** & 0.919 & ***** & 0.927 & ***** & 0.990 & ***** & 0.930 & **** & 0.940 & ***** & 0.890 & 米* \\
\hline & AIC & -7.379 & & -7.534 & & -7.352 & & -7.129 & & -7.994 & & -8.075 & & -7.692 & \\
\hline & BIC & -7.375 & & -7.530 & & -7.348 & & -7.125 & & -7.990 & & -8.071 & & -7.688 & \\
\hline & $\log \mathrm{L}$ & 5539 & & 5655 & & 5515 & & 5348 & & 5996 & & 6057 & & 5770 & \\
\hline \multirow[t]{7}{*}{$\begin{array}{c}\text { GJRGARCH- } \\
\mathbf{N} \\
\end{array}$} & $\omega_{0}\left(\begin{array}{lll}x & 10^{-6}\end{array}\right)$ & 0.503 & **** & 0.548 & ***** & 0.415 & **** & 1.660 & ****** & 0.305 & **** & 0.572 & **** & 1.250 & **** \\
\hline & $\alpha_{\mathrm{i}}$ & 0.135 & ***** & 0.105 & ****** & 0.106 & ****** & 0.101 & 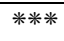 & 0.095 & **** & 0.095 & 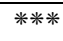 & 0.179 & **** \\
\hline & $\gamma_{\mathrm{i}} \mathrm{d}_{\mathrm{t}-\mathrm{i}}$ & 0.054 & ***** & 0.063 & ***** & 0.030 & *** & -0.008 & & 0.043 & **** & 0.054 & ***** & 0.020 & $*$ \\
\hline & $\beta_{j}$ & 0.846 & **** & 0.862 & ***** & 0.882 & **** & 0.882 & ***** & 0.881 & **** & 0.858 & **** & 0.796 & **** \\
\hline & AIC & -7.409 & & -7.568 & & -7.380 & & -7.255 & & -8.019 & & -8.101 & & -7.763 & \\
\hline & $\mathrm{BIC}$ & -7.395 & & -7.554 & & -7.366 & & -7.241 & & -8.005 & & -8.086 & & -7.749 & \\
\hline & $\log \mathrm{L}$ & 5564 & & 5684 & & 5539 & & 5445 & & 6018 & & 6079 & & 5826 & \\
\hline
\end{tabular}

Note: * ** and *** denote significance at the $10 \%, 5 \%$ and $1 \%$ levels, respectively. AIC (Akaike Information Criteria), BIC (Schwarz Bayesian Information Criteria) and LL (Log Likelihood) are goodness of fit criteria for parameter estimates. 
Appendix -D2. Parameter estimates under student-t distribution for sub-period with financial crisis (2005-2011).

\begin{tabular}{|c|c|c|c|c|c|c|c|c|c|c|c|c|c|c|c|}
\hline Model & $\begin{array}{c}\text { Parameters \& } \\
\text { Goodness of Fit } \\
\text { Criteria }\end{array}$ & $\begin{array}{l}\text { Growth } \\
\text { Fund } \\
\text { Index }\end{array}$ & & $\begin{array}{l}\text { Growth \& } \\
\text { Income } \\
\text { Fund Index }\end{array}$ & & $\begin{array}{l}\text { Income } \\
\text { Fund } \\
\text { Index }\end{array}$ & & $\begin{array}{c}\text { Bal. } \\
\text { Growth } \\
\text { Fund } \\
\text { Index }\end{array}$ & & $\begin{array}{c}\text { Bal. } \\
\text { Growth \& } \\
\text { Income } \\
\text { Fund } \\
\text { Index }\end{array}$ & & $\begin{array}{c}\text { Bal. } \\
\text { Income } \\
\text { Fund } \\
\text { Index }\end{array}$ & & $\begin{array}{c}\text { Mixed } \\
\text { Asset } \\
\text { Growth } \\
\text { Fund Index }\end{array}$ & \\
\hline \multirow[t]{6}{*}{ GARCH-t } & $\omega_{0}\left(\begin{array}{ll}x & 10^{-6}\end{array}\right)$ & 0.418 & 米*** & 0.444 & ***** & 0.289 & *** & 0.761 & ***** & 0.271 & 米* & 0.330 & ****** & 1.310 & 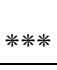 \\
\hline & $\alpha_{\mathrm{i}}$ & 0.143 & ****** & 0.134 & ******* & 0.097 & ***** & 0.142 & ***** & 0.119 & ****** & 0.103 & ******* & 0.153 & ****** \\
\hline & $\beta_{\mathrm{j}}$ & 0.866 & 米** & 0.872 & 米*** & 0.909 & ***** & 0.865 & ***** & 0.890 & ***** & 0.891 & ***** & 0.823 & ***** \\
\hline & AIC & -7.473 & & -7.644 & & -7.493 & & -7.607 & & -8.139 & & -8.173 & & -7.938 & \\
\hline & BIC & -7.459 & & -7.630 & & -7.479 & & -7.593 & & -8.125 & & -8.159 & & -7.924 & \\
\hline & $\log \mathrm{L}$ & 5612 & & 5741 & & 5624 & & 5709 & & 6108 & & 6134 & & 5958 & \\
\hline \multirow[t]{7}{*}{ EGARCH-t } & $\omega_{0}\left(\begin{array}{lll} & \left.10^{-6}\right)\end{array}\right.$ & -0.436 & **** & -0.386 & ***** & -0.278 & **** & -0.267 & **** & -0.369 & 米*** & -0.386 & ***** & -0.722 & ***** \\
\hline & $\alpha_{\mathrm{i}}$ & 0.269 & **** & 0.239 & ****** & 0.201 & **** & 0.156 & **** & 0.214 & ***** & 0.203 & ****** & 0.260 & ***** \\
\hline & $\beta_{\mathrm{j}}$ & 0.976 & ***** & 0.979 & ****** & 0.987 & ***** & 0.984 & ***** & 0.979 & ***** & 0.978 & ******* & 0.949 & ***** \\
\hline & $\gamma_{\mathrm{i}}$ & -0.047 & ***** & -0.046 & ***** & -0.036 & **** & -0.002 & & -0.042 & ***** & -0.037 & *** & -0.062 & ***** \\
\hline & AIC & 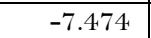 & & -7.644 & & -7.501 & & -7.615 & & -8.143 & & -8.176 & & -7.944 & \\
\hline & BIC & -7.457 & & -7.626 & & -7.483 & & -7.598 & & -8.126 & & -8.159 & & -7.927 & \\
\hline & $\log \mathrm{L}$ & 5614 & & 5742 & & 5631 & & 5717 & & 6113 & & 6137 & & 5963 & \\
\hline \multirow[t]{5}{*}{ IGARCH-t } & $\alpha_{\mathrm{i}}$ & 0.096 & **** & 0.087 & ***** & 0.061 & **** & 0.080 & ***** & 0.079 & ****** & 0.061 & ***** & 0.094 & ***** \\
\hline & $\beta_{\mathrm{j}}$ & 0.904 & 米*** & 0.913 & ***** & 0.939 & ***** & 0.920 & ****** & 0.921 & 米*** & 0.939 & ***** & 0.906 & 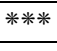 \\
\hline & AIC & -7.460 & & -7.629 & & -7.485 & & -7.588 & & -8.126 & & -8.165 & & -7.906 & \\
\hline & BIC & \begin{tabular}{l|l|}
-7.453 \\
\end{tabular} & & -7.622 & & -7.478 & & -7.580 & & -8.119 & & -8.157 & & -7.899 & \\
\hline & $\log \mathrm{L}$ & 5601 & & 5728 & & 5616 & & 5693 & & 6096 & & 6125 & & 5932 & \\
\hline \multirow[t]{7}{*}{ GJRGARCH-t } & $\omega_{0}\left(\begin{array}{lll}x^{-6} & \left.10^{-6}\right)\end{array}\right.$ & 0.500 & 米*** & 0.536 & 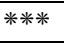 & 0.3300 & **** & 0.737 & ***** & 0.299 & ***** & 0.398 & ***** & 1.710 & 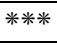 \\
\hline & $\alpha_{\mathrm{i}}$ & 0.124 & ***** & 0.114 & ******* & 0.089 & ***** & 0.145 & ***** & 0.103 & ***** & 0.087 & ****** & 0.106 & **** \\
\hline & $\gamma_{\mathrm{i}} \mathrm{d}_{\mathrm{t}-\mathrm{i}}$ & 0.057 & * & 0.057 & * & 0.024 & & -0.008 & & 0.031 & & 0.043 & & 0.120 & **** \\
\hline & $\beta_{\mathrm{j}}$ & 0.857 & ***** & 0.862 & ***** & 0.905 & **** & 0.867 & **** & 0.887 & ***** & 0.882 & ****** & 0.798 & ***** \\
\hline & AIC & -7.474 & & -7.645 & & -7.492 & & -7.605 & & -8.139 & & -8.174 & & -7.942 & \\
\hline & BIC & -7.456 & & -7.627 & & -7.475 & & -7.588 & & -8.121 & & -8.156 & & -7.924 & \\
\hline & $\log \mathrm{L}$ & 5614 & & 5742 & & 5624 & & 5709 & & 6109 & & 6135 & & 5961 & \\
\hline
\end{tabular}

Note: *, ** and **** denote significance at the $10 \%, 5 \%$ and $1 \%$ levels, respectively. AIC (Akaike Information Criteria), BIC (Schwarz Bayesian Information Criteria) and LL (Log Likelihood) are goodness of fit criteria for parameter estimates. 
Appendix -D3. Parameter estimates under GED distribution for sub-period with financial crisis (2005-2011).

\begin{tabular}{|c|c|c|c|c|c|c|c|c|c|c|c|c|c|c|c|}
\hline Model & $\begin{array}{c}\text { Parameters \& } \\
\text { Goodness of } \\
\text { Fit Criteria }\end{array}$ & $\begin{array}{l}\text { Growth } \\
\text { Fund } \\
\text { Index }\end{array}$ & & $\begin{array}{l}\text { Growth \& } \\
\text { Income } \\
\text { Fund Index }\end{array}$ & & $\begin{array}{l}\text { Income } \\
\text { Fund } \\
\text { Index }\end{array}$ & & $\begin{array}{c}\text { Bal. } \\
\text { Growth } \\
\text { Fund } \\
\text { Index } \\
\end{array}$ & & $\begin{array}{c}\text { Bal. } \\
\text { Growth \& } \\
\text { Income } \\
\text { Fund Index } \\
\end{array}$ & & $\begin{array}{c}\text { Bal. } \\
\text { Income } \\
\text { Fund } \\
\text { Index } \\
\end{array}$ & & $\begin{array}{c}\text { Mixed } \\
\text { Asset } \\
\text { Growth } \\
\text { Fund Index } \\
\end{array}$ & \\
\hline \multirow[t]{6}{*}{ GARCH-GED } & $\omega_{0}\left(\begin{array}{lll}x & 10^{-6}\end{array}\right)$ & 0.411 & **** & 0.422 & **** & 0.323 & *** & 0.897 & **** & 0.250 & *** & 0.348 & ***** & 1.220 & ***** \\
\hline & $\alpha_{\mathrm{i}}$ & 0.148 & **** & 0.128 & ***** & 0.103 & **** & 0.138 & ***** & 0.114 & ***** & 0.104 & ****** & 0.157 & ***** \\
\hline & $\beta_{\mathrm{j}}$ & 0.860 & ***** & 0.873 & ***** & 0.899 & **** & 0.867 & ***** & 0.888 & **** & 0.885 & ****** & 0.814 & ***** \\
\hline & AIC & -7.480 & & -7.653 & & -7.496 & & -7.610 & & -8.155 & & -8.177 & & -7.943 & \\
\hline & $\mathrm{BIC}$ & -7.466 & & -7.639 & & -7.481 & & -7.596 & & -8.141 & & -8.163 & & -7.929 & \\
\hline & $\log \mathrm{L}$ & 5618 & & 5748 & & 5626 & & 5711 & & 6120 & & 6137 & & 5961 & \\
\hline \multirow[t]{7}{*}{ EGARCH-GED } & $\omega_{0}\left(\begin{array}{ll}x_{1}^{-6}\end{array}\right)$ & -0.450 & ***** & -0.388 & ***** & -0.296 & **** & -0.244 & ****** & -0.370 & **** & -0.405 & ****** & -0.753 & ***** \\
\hline & $\alpha_{i}$ & 0.274 & **** & 0.232 & ***** & 0.205 & **** & 0.140 & ***** & 0.209 & **** & 0.202 & ***** & 0.274 & **** \\
\hline & $\beta_{j}$ & 0.976 & **** & 0.979 & ***** & 0.985 & ***** & 0.985 & ***** & 0.980 & ***** & 0.977 & ******* & 0.947 & ***** \\
\hline & $\gamma_{\mathrm{i}}$ & -0.047 & **** & -0.045 & ***** & -0.035 & *** & -0.006 & & -0.043 & *** & -0.039 & 米* & -0.052 & ***** \\
\hline & AIC & -7.481 & & -7.652 & & -7.503 & & -7.617 & & -8.160 & & -8.180 & & -7.946 & \\
\hline & BIC & -7.463 & & -7.635 & & -7.485 & & -7.599 & & -8.142 & & -8.162 & & -7.929 & \\
\hline & $\log \mathrm{L}$ & 5619 & & 5748 & & 5632 & & 5718 & & 6125 & & 6140 & & 5965 & \\
\hline \multirow[t]{5}{*}{ IGARCH-GED } & $\alpha_{\mathrm{i}}$ & 0.096 & **** & 0.084 & **** & 0.064 & **** & 0.016 & **** & 0.075 & **** & 0.060 & ***** & 0.098 & **** \\
\hline & $\beta_{j}$ & 0.904 & **** & 0.916 & **** & 0.936 & **** & 0.984 & **** & 0.925 & **** & 0.940 & ***** & 0.902 & **** \\
\hline & AIC & -7.468 & & -7.640 & & -7.487 & & -7.590 & & -8.144 & & -8.169 & & -7.914 & \\
\hline & $\mathrm{BIC}$ & -7.461 & & -7.633 & & -7.480 & & -7.583 & & -8.137 & & -8.162 & & -7.907 & \\
\hline & $\log \mathrm{L}$ & 5607 & & 5736 & & 5617 & & 5695 & & 6110 & & 6129 & & 5938 & \\
\hline \multirow[t]{7}{*}{$\begin{array}{c}\text { GJRGARCH- } \\
\text { GED } \\
\end{array}$} & $\omega_{0}\left(\begin{array}{lll}\mathrm{x} & \left.10^{-6}\right)\end{array}\right.$ & 0.491 & **** & 0.515 & **** & 0.359 & **** & 0.835 & **** & 0.280 & *** & 0.421 & **** & 1.490 & **** \\
\hline & $\alpha_{i}$ & 0.126 & **** & 0.107 & **** & 0.092 & **** & 0.144 & **** & 0.095 & **** & 0.085 & ****** & 0.122 & ***** \\
\hline & $\gamma_{\mathrm{i}} \mathrm{d}_{\mathrm{t}-\mathrm{i}}$ & 0.057 & * & 0.055 & * & 0.025 & & -0.021 & & 0.035 & & 0.045 & * & 0.085 & *** \\
\hline & $\beta_{j}$ & 0.853 & **** & 0.864 & ***** & 0.896 & **** & 0.871 & **** & 0.886 & **** & 0.878 & ****** & 0.797 & ***** \\
\hline & AIC & -7.481 & & -7.654 & & -7.495 & & -7.609 & & -8.155 & & -8.178 & & -7.944 & \\
\hline & $\mathrm{BIC}$ & -7.464 & & -7.637 & & -7.477 & & -7.591 & & -8.137 & & -8.160 & & -7.927 & \\
\hline & $\log \mathrm{L}$ & 5620 & & 5750 & & 5626 & & 5712 & & 6121 & & 6138 & & 5963 & \\
\hline
\end{tabular}

Note: *, *** and **** denote significance at the 10\%, $5 \%$ and $1 \%$ levels, respectively. AIC (Akaike Information Criteria), BIC (Schwarz Bayesian Information Criteria) and LL (Log Likelihood) are goodness of fit criteria for parameter estimates. 
Appendix -D4. Parameter estimates under Gaussian distribution for sub-period without financial crisis (2012-2019).

\begin{tabular}{|c|c|c|c|c|c|c|c|c|c|c|c|c|c|c|c|}
\hline Model & $\begin{array}{c}\text { Parameters } \\
\& \\
\text { Goodness } \\
\text { of Fit } \\
\text { Criteria } \\
\end{array}$ & $\begin{array}{l}\text { Growth } \\
\text { Fund } \\
\text { Index }\end{array}$ & & $\begin{array}{l}\text { Growth \& } \\
\text { Income } \\
\text { Fund Index }\end{array}$ & & $\begin{array}{l}\text { Income } \\
\text { Fund } \\
\text { Index }\end{array}$ & & $\begin{array}{c}\text { Bal. } \\
\text { Growth } \\
\text { Fund Index }\end{array}$ & & $\begin{array}{l}\text { Bal. Growth } \\
\& \text { Income } \\
\text { Fund Index }\end{array}$ & & $\begin{array}{l}\text { Bal. Income } \\
\text { Fund Index }\end{array}$ & & $\begin{array}{c}\text { Mixed } \\
\text { Asset } \\
\text { Growth } \\
\text { Fund } \\
\text { Index } \\
\end{array}$ & \\
\hline \multirow[t]{6}{*}{ GARCH-N } & $\omega_{0}\left(\begin{array}{lll} & \left.10^{-6}\right)\end{array}\right.$ & 1.020 & **** & 0.903 & **** & 1.490 & ***** & 0.441 & **** & 0.661 & **** & 0.817 & ***** & 8.620 & **** \\
\hline & $\alpha_{\mathrm{i}}$ & 0.104 & ****** & 0.088 & ****** & 0.074 & ***** & 0.139 & ****** & 0.087 & **** & 0.116 & ****** & 0.105 & **** \\
\hline & $\beta_{\mathrm{j}}$ & 0.842 & ***** & 0.852 & **** & 0.863 & ***** & 0.848 & ***** & 0.832 & **** & 0.806 & ***** & 0.624 & ***** \\
\hline & AIC & -8.195 & & -8.357 & & -7.920 & & -8.575 & & -8.953 & & -8.756 & & -7.587 & \\
\hline & $\mathrm{BIC}$ & -8.185 & & -8.347 & & -7.909 & & -8.564 & & -8.942 & & -8.746 & & -7.577 & \\
\hline & $\log \mathrm{L}$ & 6150 & & 6271 & & 5943 & & 6434 & & 6718 & & 6570 & & 5694 & \\
\hline \multirow[t]{7}{*}{ EGARCH-N } & $\omega_{0}\left(x_{10^{-6}}\right)$ & -0.862 & ***** & -1.172 & ***** & -0.653 & **** & -1.136 & ******* & -0.963 & **** & -1.089 & ***** & -1.357 & **** \\
\hline & $\alpha_{\mathrm{i}}$ & 0.187 & ***** & 0.167 & 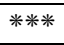 & 0.107 & ***** & 0.294 & ******* & 0.133 & **** & 0.176 & 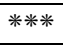 & 0.071 & **** \\
\hline & $\beta_{\mathrm{j}}$ & 0.934 & ****** & 0.906 & **** & 0.946 & ***** & 0.918 & ******* & 0.926 & **** & 0.917 & ****** & 0.875 & ***** \\
\hline & $\gamma_{\mathrm{i}}$ & -0.108 & ***** & -0.126 & **** & -0.087 & ***** & -0.169 & ***** & -0.100 & 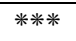 & -0.124 & 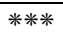 & -0.143 & **** \\
\hline & AIC & -8.215 & & -8.382 & & -7.936 & & -8.616 & & -8.971 & & -8.778 & & -7.626 & \\
\hline & $\mathrm{BIC}$ & -8.201 & & -8.367 & & -7.922 & & -8.602 & & -8.956 & & -8.763 & & -7.611 & \\
\hline & $\log \mathrm{L}$ & 6166 & & 6290 & & 5956 & & 6466 & & 6732 & & 6587 & & 5723 & \\
\hline \multirow[t]{5}{*}{ IGARCH-N } & $\alpha_{\mathrm{i}}$ & 0.061 & ***** & 0.066 & **** & 0.009 & ****** & 0.095 & ******* & 0.033 & ***** & 0.052 & ****** & 0.009 & ***** \\
\hline & $\beta_{\mathrm{j}}$ & 0.939 & ****** & 0.934 & 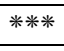 & 0.991 & ***** & 0.905 & ******* & 0.967 & ***** & 0.948 & ****** & 0.991 & ***** \\
\hline & AIC & -8.153 & & -8.315 & & -7.832 & & -8.507 & & -8.888 & & -8.722 & & -7.572 & \\
\hline & $\mathrm{BIC}$ & -8.149 & & -8.311 & & -7.828 & & -8.602 & & -8.885 & & -8.719 & & -7.568 & \\
\hline & $\log \mathrm{L}$ & 6116 & & 6237 & & 5875 & & 6381 & & 6667 & & 6543 & & 5680 & \\
\hline \multirow[t]{7}{*}{$\begin{array}{l}\text { GJRGARCH- } \\
\mathbf{N}\end{array}$} & $\omega_{0}\left(\begin{array}{lll}x^{-6}\end{array}\right)$ & 1.520 & ***** & 1.900 & ***** & 1.500 & ***** & 1.150 & ****** & 0.714 & ***** & 1.240 & ***** & 8.770 & ***** \\
\hline & $\alpha_{i}$ & 0.044 & ***** & 0.029 & ****** & 0.014 & & 0.061 & ****** & 0.027 & 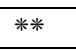 & 0.051 & ***** & -0.005 & \\
\hline & $\gamma_{\mathrm{i}} \mathrm{d}_{\mathrm{t}-\mathrm{i}}$ & 0.153 & ***** & 0.168 & ***** & 0.083 & **** & 0.346 & **⿻丷木大 & 0.108 & **** & 0.191 & ***** & 0.176 & ***** \\
\hline & $\beta_{j}$ & 0.795 & ***** & 0.756 & ***** & 0.874 & **** & 0.723 & **⿻丷木大 & 0.827 & **** & 0.734 & ***** & 0.652 & ***** \\
\hline & AIC & -8.214 & & -8.373 & & -7.928 & & -8.600 & & -8.967 & & -8.773 & & -7.607 & \\
\hline & BIC & -8.199 & & -8.359 & & -7.914 & & -8.586 & & -8.953 & & -8.759 & & -7.593 & \\
\hline & $\log \mathrm{L}$ & 6164 & & 6284 & & 5950 & & 6454 & & 6729 & & 6584 & & 5709 & \\
\hline
\end{tabular}

Note: *, ** and **** denote significance at the $10 \%, 5 \%$ and $1 \%$ levels, respectively. AIC (Akaike Information Criteria), BIC (Schwarz Bayesian Information Criteria) and LL (Log Likelihood) are goodness of fit criteria for parameter estimates. 
Appendix -D5. Parameter estimates under student-t distribution for sub-period without financial crisis (2012-2019).

\begin{tabular}{|c|c|c|c|c|c|c|c|c|c|c|c|c|c|c|c|}
\hline Model & $\begin{array}{l}\text { Parameters \& } \\
\text { Goodness of } \\
\text { Fit Criteria }\end{array}$ & $\begin{array}{l}\text { Growth } \\
\text { Fund } \\
\text { Index }\end{array}$ & & $\begin{array}{l}\text { Growth \& } \\
\text { Income } \\
\text { Fund Index }\end{array}$ & & $\begin{array}{l}\text { Income } \\
\text { Fund } \\
\text { Index }\end{array}$ & & $\begin{array}{l}\text { Balanced } \\
\text { Growth } \\
\text { Fund Index }\end{array}$ & & $\begin{array}{c}\text { Balanced } \\
\text { Growth \& } \\
\text { Income } \\
\text { Fund Index } \\
\end{array}$ & & $\begin{array}{l}\text { Balanced } \\
\text { Income } \\
\text { Fund Index }\end{array}$ & & $\begin{array}{c}\text { Mixed } \\
\text { Asset } \\
\text { Growth } \\
\text { Fund Index } \\
\end{array}$ & \\
\hline \multirow{6}{*}{ GARCH-t } & $\omega_{0}\left(\mathrm{x}^{1} 1^{-6}\right)$ & 1.000 & **** & 1.280 & **** & 1.990 & ****** & 0.981 & ****** & 0.465 & ***** & 0.568 & ****** & 4.320 & ***** \\
\hline & $\alpha_{\mathrm{i}}$ & 0.114 & ***** & 0.126 & ****** & 0.112 & ***** & 0.146 & ****** & 0.092 & ***** & 0.107 & ******** & 0.139 & ******* \\
\hline & $\beta_{j}$ & 0.834 & **** & 0.794 & ***** & 0.814 & ***** & 0.786 & ****** & 0.857 & **** & 0.842 & ***** & 0.728 & ***** \\
\hline & AIC & -8.296 & & -8.458 & & -8.119 & & -8.810 & & -9.071 & & -8.836 & & -7.943 & \\
\hline & BIC & -8.282 & & -8.444 & & -8.105 & & -8.796 & & -9.057 & & -8.822 & & -7.929 & \\
\hline & LogL & 6226 & & 6348 & & 6094 & & 6612 & & 6807 & & 6631 & & 5961 & \\
\hline \multirow[t]{7}{*}{$\begin{array}{c}\text { EGARCH- } \\
t \\
\end{array}$} & $\omega_{0}\left(\times 10^{-6}\right)$ & -0.778 & **** & -1.071 & ***** & -0.869 & ***** & -1.069 & ***** & -0.759 & ***** & -0.758 & ***** & -1.035 & ***** \\
\hline & $\alpha_{i}$ & 0.202 & ***** & 0.196 & **** & 0.151 & **** & 0.253 & ****** & 0.153 & ***** & 0.169 & ***** & 0.164 & **** \\
\hline & $\beta_{\mathrm{j}}$ & 0.943 & ***** & 0.917 & **** & 0.929 & ***** & 0.922 & ***** & 0.945 & ***** & 0.945 & ***** & 0.912 & **** \\
\hline & $\gamma_{\mathrm{i}}$ & -0.098 & **** & -0.112 & **** & -0.111 & **** & -0.072 & ***** & -0.086 & ***** & -0.096 & ***** & -0.090 & **** \\
\hline & AIC & -8.304 & & -8.469 & & -8.133 & & -8.815 & & -9.077 & & -8.844 & & -7.954 & \\
\hline & BIC & -8.287 & & -8.451 & & -8.115 & & -8.797 & & -9.059 & & -8.826 & & -7.936 & \\
\hline & $\log \mathrm{L}$ & 6233 & & 6357 & & 6105 & & 6616 & & 6812 & & 6638 & & 5970 & \\
\hline \multirow[t]{5}{*}{ IGARCH-t } & $\alpha_{\mathrm{i}}$ & 0.079 & **** & 0.079 & **** & 0.020 & **** & 0.011 & ****** & 0.058 & ***** & 0.061 & ***** & 0.016 & **** \\
\hline & $\beta_{j}$ & 0.921 & ***** & 0.921 & **** & 0.980 & **** & 0.989 & ***** & 0.942 & ***** & 0.939 & ***** & 0.984 & **** \\
\hline & AIC & -8.269 & & -8.426 & & -8.081 & & -8.747 & & -9.047 & & -8.816 & & -7.930 & \\
\hline & $\mathrm{BIC}$ & -8.262 & & -8.419 & & -8.074 & & -8.740 & & -9.040 & & -8.809 & & -7.923 & \\
\hline & $\operatorname{LogL}$ & 6204 & & 6322 & & 6063 & & 6563 & & 6788 & & 6614 & & 5950 & \\
\hline \multirow[t]{7}{*}{$\begin{array}{c}\text { GJRGARC } \\
\text { H-t }\end{array}$} & $\omega_{0}\left(\times 10^{-6}\right)$ & 1.220 & **** & 1.590 & ***** & 2.460 & **** & 1.150 & **** & 0.558 & **** & 0.716 & **** & 5.250 & ***** \\
\hline & $\alpha_{i}$ & 0.051 & *** & 0.045 & * & 0.036 & & 0.116 & ****** & 0.040 & * & 0.050 & *** & 0.032 & \\
\hline & $\gamma_{\mathrm{i}} \mathrm{d}_{\mathrm{t}-\mathrm{i}}$ & 0.130 & **** & 0.153 & **** & 0.136 & ***** & 0.073 & & 0.091 & **** & 0.117 & ***** & 0.191 & ***** \\
\hline & $\beta_{\mathrm{j}}$ & 0.817 & **** & 0.771 & **** & 0.794 & **** & 0.763 & ***** & 0.847 & ***** & 0.822 & **** & 0.695 & ***** \\
\hline & AIC & -8.305 & & -8.467 & & -8.124 & & -8.810 & & -9.076 & & -8.842 & & -7.948 & \\
\hline & BIC & -8.287 & & -8.450 & & -8.107 & & -8.792 & & -9.058 & & -8.824 & & -7.931 & \\
\hline & $\log \mathrm{L}$ & 6234 & & 6356 & & 6098 & & 6612 & & 6812 & & 6637 & & 5966 & \\
\hline
\end{tabular}

Note: * ** and *** denote significance at the $10 \%, 5 \%$ and $1 \%$ levels, respectively. AIC (Akaike Information Criteria), BIC (Schwarz Bayesian Information Criteria) and LL (Log Likelihood) are goodness of fit criteria for parameter estimates. 
Appendix -D6. Parameter estimates under GED distribution for sub-period without financial crisis (2012-2019).

\begin{tabular}{|c|c|c|c|c|c|c|c|c|c|c|c|c|c|c|c|}
\hline Model & $\begin{array}{l}\text { Parameters \& } \\
\text { Goodness of } \\
\text { Fit Criteria }\end{array}$ & $\begin{array}{l}\text { Growth } \\
\text { Fund } \\
\text { Index }\end{array}$ & & $\begin{array}{l}\text { Growth \& } \\
\text { Income Fund } \\
\text { Index }\end{array}$ & & $\begin{array}{l}\text { Income } \\
\text { Fund } \\
\text { Index }\end{array}$ & & $\begin{array}{l}\text { Balanced } \\
\text { Growth } \\
\text { Fund Index }\end{array}$ & & $\begin{array}{c}\text { Balance } \\
\quad d \\
\text { Growth } \\
\& \\
\text { Income } \\
\text { Fund } \\
\text { Index }\end{array}$ & & $\begin{array}{c}\text { Balance } \\
\quad d \\
\text { Income } \\
\text { Fund } \\
\text { Index }\end{array}$ & & $\begin{array}{l}\text { Mixed } \\
\text { Asset } \\
\text { Growt } \\
\text { h Fund } \\
\text { Index }\end{array}$ & \\
\hline \multirow[t]{6}{*}{ GARCH-GED } & $\omega_{0}\left(\times 10^{-6}\right)$ & 1.030 & ******* & 1.190 & 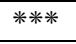 & 1.740 & ****** & 3.340 & **** & 0.525 & ***** & 0.654 & ******* & 5.150 & ******* \\
\hline & $\alpha_{i}$ & 0.113 & ******* & 0.113 & 米米米 & 0.096 & ****** & 0.573 & ***** & 0.088 & ***** & 0.106 & ****** & 0.128 & ****** \\
\hline & $\beta_{\mathrm{j}}$ & 0.833 & ****** & 0.809 & ***** & 0.830 & ***** & 0.740 & ***** & 0.850 & 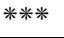 & 0.831 & ****** & 0.695 & ***** \\
\hline & AIC & -8.298 & & -8.457 & & -8.124 & & -8.871 & & -9.080 & & -8.842 & & -7.929 & \\
\hline & BIC & -8.283 & & -8.442 & & -8.110 & & -8.856 & & -9.066 & & -8.828 & & -7.915 & \\
\hline & LL & 6227 & & 6346 & & 6097 & & 6657 & & 6814 & & 6635 & & 5951 & \\
\hline \multirow[t]{7}{*}{ EGARCH-GED } & $\omega_{0}\left(\mathrm{x} 10^{-6}\right)$ & -0.811 & ***** & -1.117 & 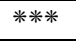 & -0.806 & ******* & -1.215 & ****** & -0.844 & **** & -0.915 & ******* & -1.275 & 米米米 \\
\hline & $\alpha_{\mathrm{i}}$ & 0.198 & ******* & 0.185 & ****** & 0.137 & 米米米 & 0.513 & ******* & 0.143 & ***** & 0.172 & ******** & 0.149 & 米米米 \\
\hline & $\beta_{j}$ & 0.940 & ***** & 0.913 & ****** & 0.934 & ****** & 0.903 & 米米 & 0.937 & ***** & 0.932 & ****** & 0.889 & 米米米 \\
\hline & $\gamma_{\mathrm{i}}$ & -0.102 & ****** & -0.116 & ******* & -0.104 & ****** & -0.150 & & -0.095 & ***** & -0.106 & 米米 & -0.105 & 米米米 \\
\hline & AIC & -8.307 & & -8.468 & & -8.135 & & \begin{tabular}{|l|l|}
-8.873 \\
\end{tabular} & & -9.087 & & -8.851 & & -7.939 & \\
\hline & BIC & -8.289 & & -8.450 & & -8.117 & & -8.856 & & -9.070 & & -8.833 & & -7.921 & \\
\hline & LL & 6235 & & 6356 & & 6106 & & 6660 & & 6821 & & 6643 & & 5959 & \\
\hline \multirow[t]{5}{*}{ IGARCH-GED } & $\alpha_{\mathrm{i}}$ & 0.072 & ***** & 0.073 & ***** & 0.017 & ****** & 0.008 & ****** & 0.048 & ***** & 0.056 & ******* & 0.014 & ****** \\
\hline & $\beta_{\mathrm{j}}$ & 0.928 & ****** & 0.927 & 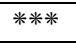 & 0.983 & ****** & 0.992 & ***** & 0.952 & ***** & 0.944 & ****** & 0.986 & ****** \\
\hline & AIC & -8.273 & & -8.430 & & -8.090 & & -8.824 & & -9.055 & & -8.823 & & $\begin{array}{l}-7.919 \\
\end{array}$ & \\
\hline & BIC & -8.266 & & -8.422 & & -8.083 & & -8.817 & & -9.048 & & -8.816 & & $\begin{array}{l}-7.912 \\
\end{array}$ & \\
\hline & LL & 6207 & & 6324 & & 6069 & & 6620 & & 6794 & & 6619 & & 5941 & \\
\hline \multirow[t]{7}{*}{$\begin{array}{l}\text { GJRGARCH- } \\
\text { GED } \\
\end{array}$} & $\omega_{0}\left(\mathrm{x} \quad 10^{-6}\right)$ & 1.350 & ***** & 1.760 & ***** & 2.060 & ***** & 4.870 & ***** & 0.626 & ***** ～～～ & 0.941 & ****** & 6.350 & 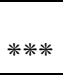 \\
\hline & $\alpha_{i}$ & 0.049 & ***** & 0.038 & & 0.028 & & 0.436 & & 0.031 & & 0.049 & * & -0.004 & \\
\hline & $\gamma_{\mathrm{i}} \mathrm{d}_{\mathrm{t}-\mathrm{i}}$ & 0.143 & ****** & 0.163 & 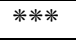 & 0.112 & ******* & 0.483 & & 0.102 & ***** & 0.142 & ******* & 0.240 & ****** \\
\hline & $\beta_{\mathrm{j}}$ & 0.804 & ***** & 0.758 & ***** & 0.821 & ****** & 0.668 & ***** & 0.838 & **** & 0.787 & ******* & 0.658 & ***** \\
\hline & AIC & -8.307 & & -8.466 & & -8.128 & & -8.870 & & -9.086 & & -8.849 & & -7.935 & \\
\hline & BIC & -8.289 & & -8.448 & & -8.110 & & -8.852 & & -9.068 & & -8.831 & & -7.918 & \\
\hline & LL & 6235 & & 6354 & & 6101 & & 6658 & & 6819 & & 6642 & & 5957 & \\
\hline
\end{tabular}

Note: *, *** and **** denote significance at the 10\%, $5 \%$ and $1 \%$ levels, respectively. AIC (Akaike Information Criteria), BIC (Schwarz Bayesian Information Criteria) and LL (Log Likelihood) are goodness of fit criteria for parameter estimates. 
Appendix -E1. Post-sample volatility performance under MAE criteria (2005-2011)

\begin{tabular}{|c|c|c|c|c|c|c|c|c|c|}
\hline Models & $\begin{array}{l}\text { Growth } \\
\text { Fund } \\
\text { Index }\end{array}$ & $\begin{array}{c}\text { Growth } \\
\quad \& \\
\text { Income } \\
\text { Fund } \\
\text { Index }\end{array}$ & $\begin{array}{l}\text { Income } \\
\text { Fund } \\
\text { Index }\end{array}$ & $\begin{array}{c}\text { Balanced } \\
\text { Growth } \\
\text { Fund } \\
\text { Index }\end{array}$ & $\begin{array}{c}\text { Balanced } \\
\text { Growth } \\
\& \\
\text { Income } \\
\text { Fund } \\
\text { Index }\end{array}$ & $\begin{array}{l}\text { Balanced } \\
\text { Income } \\
\text { Fund } \\
\text { Index }\end{array}$ & $\begin{array}{c}\text { Mixed } \\
\text { Asset } \\
\text { Growth } \\
\text { Fund } \\
\text { Index }\end{array}$ & $\begin{array}{c}\text { Mean } \\
\text { Theil- } \\
\text { U }\end{array}$ & Rank \\
\hline $\mathrm{RW}$ & 54.42 & 38.51 & 48.36 & 39.92 & 24.16 & 29.41 & 38.81 & 1.120 & 21 \\
\hline Naïve Variance & 56.17 & 44.15 & 54.30 & 51.73 & 25.83 & 26.06 & 37.05 & 1.193 & 22 \\
\hline MA30 & 44.43 & 31.59 & 39.23 & 32.62 & 19.32 & 23.38 & 31.23 & 0.905 & 9 \\
\hline EWMA RiskMetric & 43.95 & 31.28 & 39.00 & 32.41 & 19.20 & 23.17 & 30.70 & 0.897 & 3 \\
\hline EWMA Optimized & 43.76 & 31.26 & 39.32 & 32.95 & 19.30 & 23.09 & 30.87 & 0.900 & 6 \\
\hline STES-SE & 43.71 & 31.23 & 39.28 & 32.67 & 19.29 & 23.08 & 30.84 & 0.899 & 4 \\
\hline STES-E & 43.81 & 31.29 & 39.35 & 33.16 & 19.31 & 23.10 & 30.90 & 0.902 & 8 \\
\hline STES-AbsE & 42.76 & 30.62 & 38.53 & 30.71 & 19.02 & 22.75 & 30.16 & 0.877 & 2 \\
\hline STES E+AbsE & 42.24 & 30.37 & 37.89 & 31.29 & 18.72 & 22.16 & 29.47 & 0.866 & 1 \\
\hline STES E+SE & 43.82 & 31.31 & 39.33 & 33.06 & 19.31 & 23.09 & 30.88 & 0.901 & 7 \\
\hline GARCH-N & 46.41 & 32.83 & 41.63 & 37.91 & 20.47 & 23.60 & 30.94 & 0.952 & 12 \\
\hline EGARCH-N & 47.31 & 34.29 & 42.62 & 36.54 & 20.92 & 23.74 & 33.18 & 0.971 & 14 \\
\hline IGARCH-N & 43.75 & 31.24 & 39.09 & 32.83 & 19.21 & 23.17 & 30.94 & 0.899 & 5 \\
\hline GJRGARCH-N & 46.81 & 33.24 & 41.73 & 37.82 & 20.66 & 23.52 & 33.35 & 0.966 & 13 \\
\hline GARCH-t & 46.48 & 41.43 & 41.85 & 36.92 & 21.07 & 23.84 & 32.78 & 0.991 & 18 \\
\hline EGARCH-t & 47.79 & 42.56 & 43.14 & 34.28 & 21.63 & 24.05 & 32.92 & 0.999 & 19 \\
\hline IGARCH-t & 43.75 & 37.74 & 39.00 & 32.69 & 19.23 & 23.16 & 30.83 & 0.920 & 11 \\
\hline GJRGARCH-t & 47.08 & 42.63 & 42.03 & 36.73 & 21.22 & 23.80 & 33.28 & 1.000 & 20 \\
\hline GARCH-GED & 46.09 & 40.87 & 41.04 & 37.15 & 20.45 & 23.51 & 32.12 & 0.977 & 16 \\
\hline EGARCH-GED & 47.21 & 41.77 & 42.17 & 34.72 & 21.00 & 23.67 & 32.12 & 0.983 & 17 \\
\hline IGARCH-GED & 43.75 & 37.74 & 39.02 & 32.26 & 19.22 & 23.17 & 30.85 & 0.918 & 10 \\
\hline GJRGARCH-GED & 43.75 & 41.98 & 41.18 & 36.70 & 20.63 & 23.44 & 32.32 & 0.974 & 15 \\
\hline
\end{tabular}


Appendix -E2. Post-sample volatility performance under RMSE criteria (2005-2011).

\begin{tabular}{|c|c|c|c|c|c|c|c|c|c|}
\hline Models & $\begin{array}{c}\text { Growth } \\
\text { Fund } \\
\text { Index }\end{array}$ & $\begin{array}{c}\text { Growth } \\
\qquad \& \\
\text { Income } \\
\text { Fund } \\
\text { Index }\end{array}$ & $\begin{array}{c}\text { Income } \\
\text { Fund } \\
\text { Index }\end{array}$ & $\begin{array}{c}\text { Balance } \\
\text { d } \\
\text { Growth } \\
\text { Fund } \\
\text { Index }\end{array}$ & $\begin{array}{c}\text { Balance } \\
\text { d } \\
\text { Growth } \\
\& \\
\text { Income } \\
\text { Fund } \\
\text { Index }\end{array}$ & $\begin{array}{c}\text { Balance } \\
\quad d \\
\text { Income } \\
\text { Fund } \\
\text { Index }\end{array}$ & $\begin{array}{c}\text { Mixed } \\
\text { Asset } \\
\text { Growth } \\
\text { Fund } \\
\text { Index }\end{array}$ & $\begin{array}{c}\text { Mean } \\
\text { Theil } \\
\text {-U }\end{array}$ & Rank \\
\hline $\mathrm{RW}$ & 97.99 & 67.55 & 88.01 & 176.19 & 43.95 & 52.40 & 75.29 & 1.229 & 22 \\
\hline Naïve Variance & 84.61 & 60.36 & 77.47 & 133.26 & 36.55 & 40.38 & 61.47 & 1.017 & 21 \\
\hline МАзо & 81.95 & 56.78 & 73.29 & 132.81 & 34.72 & 39.81 & 60.63 & 0.984 & 14 \\
\hline $\begin{array}{l}\text { EWMA (0.6) } \\
\text { RiskMetric }\end{array}$ & 80.63 & 55.80 & 71.99 & 132.80 & 34.52 & 39.31 & 59.90 & 0.973 & 4 \\
\hline $\begin{array}{l}\text { EWMA } \\
\text { Optimized }\end{array}$ & 80.42 & 55.70 & 71.78 & 133.92 & 34.62 & 39.27 & 60.01 & 0.973 & 8 \\
\hline STES-SE & 80.41 & 55.69 & 71.77 & 133.72 & 34.62 & 39.27 & 59.99 & 0.973 & 6 \\
\hline STES-E & 80.42 & 55.70 & 71.77 & 134.06 & 34.61 & 39.26 & 60.02 & 0.973 & 9 \\
\hline STES-AbsE & 80.32 & 55.65 & 71.77 & 132.80 & 34.62 & 39.26 & 59.87 & 0.971 & 3 \\
\hline STES E+AbsE & 79.97 & 55.53 & 71.38 & 133.41 & 34.45 & 39.01 & 59.79 & 0.969 & 1 \\
\hline STES E+SE & 80.40 & 55.69 & 71.74 & 133.91 & 34.59 & 39.25 & 60.00 & 0.973 & 5 \\
\hline GARCH-N & 81.30 & 55.93 & 72.16 & 133.30 & 34.80 & 39.15 & 60.07 & 0.976 & 10 \\
\hline EGARCH-N & 80.97 & 56.11 & 72.46 & 131.74 & 34.75 & 38.83 & 60.03 & 0.973 & 7 \\
\hline IGARCH-N & 80.42 & 55.70 & 71.86 & 131.47 & 34.53 & 39.31 & 60.07 & 0.971 & 2 \\
\hline GJRGARCH-N & 81.58 & 56.05 & 71.93 & 133.23 & 34.77 & 38.92 & 60.72 & 0.977 & 11 \\
\hline GARCH-t & 81.18 & 63.04 & 72.27 & 135.31 & 35.01 & 39.21 & 60.08 & 0.995 & 19 \\
\hline EGARCH-t & 81.13 & 63.18 & 72.63 & 131.82 & 35.07 & 38.97 & 59.68 & 0.990 & 16 \\
\hline IGARCH-t & 80.42 & 59.81 & 71.98 & 133.33 & 34.54 & 39.30 & 59.97 & 0.982 & 13 \\
\hline GJRGARCH-t & 81.65 & 64.88 & 72.06 & 135.05 & 35.02 & 39.02 & 60.80 & 1.000 & 20 \\
\hline GARCH-GED & 81.06 & 62.69 & 71.94 & 135.09 & 34.78 & 39.13 & 60.00 & 0.991 & 17 \\
\hline EGARCH-GED & 80.90 & 62.56 & 72.23 & 131.77 & 34.80 & 38.86 & 59.54 & 0.986 & 15 \\
\hline IGARCH-GED & 80.42 & 59.81 & 71.94 & 131.68 & 34.54 & 39.31 & 59.99 & 0.980 & 12 \\
\hline $\begin{array}{l}\text { GJRGARCH- } \\
\text { GED }\end{array}$ & 81.44 & 64.35 & 71.69 & 134.52 & 34.76 & 38.91 & 60.32 & 0.995 & 18 \\
\hline
\end{tabular}


Asian Economic and Financial Review, 2021, 11(10): 829-859

Appendix -E3. Post-sample volatility performance under MAE criteria (2012-2019)

\begin{tabular}{|c|c|c|c|c|c|c|c|c|c|}
\hline Models & $\begin{array}{c}\text { Growth } \\
\text { Fund } \\
\text { Index }\end{array}$ & $\begin{array}{c}\text { Growth } \\
\qquad \& \\
\text { Income } \\
\text { Fund } \\
\text { Index }\end{array}$ & $\begin{array}{l}\text { Income } \\
\text { Fund } \\
\text { Index }\end{array}$ & $\begin{array}{c}\text { Balanced } \\
\text { Growth } \\
\text { Fund } \\
\text { Index }\end{array}$ & $\begin{array}{c}\text { Balanced } \\
\text { Growth } \\
\& \\
\text { Income } \\
\text { Fund } \\
\text { Index }\end{array}$ & $\begin{array}{c}\text { Balanced } \\
\text { Income } \\
\text { Fund } \\
\text { Index }\end{array}$ & $\begin{array}{c}\text { Mixed } \\
\text { Asset } \\
\text { Growth } \\
\text { Fund } \\
\text { Index }\end{array}$ & $\begin{array}{c}\text { Mean } \\
\text { Theil- } \\
\text { U }\end{array}$ & Rank \\
\hline $\mathrm{RW}$ & 31.13 & 24.46 & 39.35 & 19.95 & 12.16 & 29.36 & 43.62 & 1.238 & 22 \\
\hline Naïve Variance & 24.96 & 19.60 & 29.55 & 16.54 & 10.02 & 20.50 & 37.25 & 0.981 & 3 \\
\hline MA30 & 26.34 & 20.29 & 31.57 & 16.77 & 10.08 & 24.59 & 37.17 & 1.033 & 18 \\
\hline EWMA RiskMetric & 25.79 & 19.90 & 31.36 & 16.56 & 10.00 & 23.98 & 36.63 & 1.017 & 15 \\
\hline EWMA Optimized & 25.78 & 19.98 & 31.26 & 16.40 & 9.95 & 24.14 & 36.8 & 1.016 & 14 \\
\hline STES-SE & 25.72 & 19.94 & 31.16 & 16.36 & 9.94 & 24.05 & 36.58 & 1.013 & 10 \\
\hline STES-E & 25.78 & 19.98 & 31.26 & 16.40 & 9.95 & 24.14 & 36.76 & 1.016 & 13 \\
\hline STES-AbsE & 24.83 & 19.29 & 29.91 & 15.76 & 9.75 & 23.06 & 34.51 & 0.975 & 2 \\
\hline STES E+AbsE & 24.41 & 19.00 & 27.44 & 15.60 & 9.61 & 22.51 & 33.53 & 0.949 & 1 \\
\hline STES E+SE & 25.72 & 19.94 & 31.16 & 16.36 & 9.94 & 24.05 & 36.58 & 1.013 & 9 \\
\hline GARCH-N & 25.02 & 19.28 & 30.18 & 16.83 & 9.92 & 21.97 & 36.96 & 0.992 & 5 \\
\hline EGARCH-N & 24.85 & 19.16 & 30.32 & 18.33 & 10.02 & 21.31 & 37.73 & 1.003 & 8 \\
\hline IGARCH-N & 25.79 & 19.90 & 31.17 & 16.83 & 9.99 & 24.29 & 37.06 & 1.022 & 16 \\
\hline GJRGARCH-N & 25.31 & 19.38 & 30.23 & 19.71 & 9.97 & 22.34 & 38.43 & 1.027 & 17 \\
\hline GARCH-t & 25.17 & 19.44 & 30.98 & 16.65 & 10.02 & 21.91 & 36.46 & 0.995 & 6 \\
\hline EGARCH-t & 25.11 & 19.34 & 30.85 & 16.59 & 10.16 & 21.25 & 36.41 & 0.990 & 4 \\
\hline IGARCH-t & 25.82 & 19.92 & 31.26 & 16.18 & 10.00 & 23.97 & 36.95 & 1.015 & 12 \\
\hline GJRGARCH-t & 25.43 & 19.59 & 31.22 & 16.86 & 10.02 & 21.76 & 36.66 & 1.000 & 7 \\
\hline GARCH-GED & 25.09 & 19.27 & 30.28 & 37.92 & 9.91 & 21.61 & 35.50 & 1.163 & 20 \\
\hline EGARCH-GED & 24.98 & 19.19 & 30.29 & 36.27 & 10.05 & 21.01 & 35.68 & 1.147 & 19 \\
\hline IGARCH-GED & 25.80 & 19.91 & 31.26 & 16.13 & 9.97 & 24.02 & 36.94 & 1.014 & 11 \\
\hline GJRGARCH-GED & 25.38 & 19.42 & 30.39 & 39.91 & 9.92 & 21.51 & 36.40 & 1.186 & 21 \\
\hline
\end{tabular}


Appendix -E4. Post-sample volatility performance under RMSE criteria (2012-2019).

\begin{tabular}{|c|c|c|c|c|c|c|c|c|c|}
\hline Models & $\begin{array}{c}\text { Growth } \\
\text { Fund } \\
\text { Index }\end{array}$ & $\begin{array}{c}\text { Growth } \\
\qquad \& \\
\text { Income } \\
\text { Fund } \\
\text { Index }\end{array}$ & $\begin{array}{c}\text { Income } \\
\text { Fund } \\
\text { Index }\end{array}$ & $\begin{array}{c}\text { Balanced } \\
\text { Growth } \\
\text { Fund } \\
\text { Index }\end{array}$ & $\begin{array}{c}\text { Balanced } \\
\text { Growth } \\
\& \\
\text { Income } \\
\text { Fund } \\
\text { Index } \\
\end{array}$ & $\begin{array}{c}\text { Balanced } \\
\text { Income } \\
\text { Fund } \\
\text { Index }\end{array}$ & $\begin{array}{c}\text { Mixed } \\
\text { Asset } \\
\text { Growth } \\
\text { Fund } \\
\text { Index }\end{array}$ & $\begin{array}{c}\text { Mean } \\
\text { Theil- } \\
\text { U }\end{array}$ & Rank \\
\hline $\mathrm{RW}$ & 68.55 & 53.51 & 84.71 & 60.32 & 24.32 & 77.25 & 99.03 & 1.319 & 22 \\
\hline Naïve Variance & 53.92 & 41.92 & 62.84 & 43.40 & 18.77 & 62.53 & 76.89 & 1.015 & 17 \\
\hline MA30 & 54.02 & 41.95 & 62.83 & 43.93 & 18.77 & 61.60 & 76.71 & 1.014 & 16 \\
\hline EWMA RiskMetric & 53.27 & 41.46 & 62.41 & 43.37 & 18.59 & 60.71 & 75.89 & 1.003 & 11 \\
\hline EWMA Optimized & 53.20 & 41.37 & 62.18 & 43.33 & 18.55 & 60.76 & 75.76 & 1.001 & 8 \\
\hline STES-SE & 53.19 & 41.36 & 62.17 & 43.31 & 18.55 & 60.73 & 75.73 & 1.001 & 7 \\
\hline STES-E & 53.20 & 41.37 & 62.18 & 43.33 & 18.55 & 60.76 & 75.76 & 1.001 & 9 \\
\hline STES-AbsE & 53.13 & 41.33 & 62.14 & 43.19 & 18.54 & 60.57 & 75.61 & 0.999 & 3 \\
\hline $\mathrm{STES} \mathrm{E}+\mathrm{AbsE}$ & 53.09 & 41.34 & 62.22 & 43.30 & 18.56 & 60.38 & 75.68 & 1.000 & 4 \\
\hline STES E+SE & 53.19 & 41.36 & 62.17 & 43.31 & 18.55 & 60.73 & 75.73 & 1.001 & 6 \\
\hline GARCH-N & 52.97 & 41.24 & 62.21 & 43.50 & 18.68 & 61.23 & 76.12 & 1.003 & 14 \\
\hline EGARCH-N & 52.27 & 40.72 & 61.56 & 45.41 & 18.53 & 60.77 & 75.98 & 1.002 & 10 \\
\hline IGARCH-N & 53.28 & 41.49 & 62.46 & 43.50 & 18.62 & 61.26 & 76.47 & 1.006 & 15 \\
\hline GJRGARCH-N & 52.91 & 41.07 & 61.98 & 48.24 & 18.69 & 62.08 & 76.52 & 1.020 & 18 \\
\hline GARCH-t & 53.02 & 41.27 & 62.45 & 43.49 & 18.53 & 60.27 & 75.36 & 0.999 & 2 \\
\hline EGARCH-t & 52.39 & 40.79 & 61.71 & 43.37 & 18.41 & 59.72 & 75.13 & 0.991 & 1 \\
\hline IGARCH-t & 53.38 & 41.57 & 62.17 & 43.44 & 18.59 & 60.72 & 76.00 & 1.003 & 13 \\
\hline GJRGARCH-t & 52.95 & 41.20 & 62.58 & 43.94 & 18.48 & 59.90 & 75.74 & 1.000 & 5 \\
\hline GARCH-GED & 53.01 & 41.24 & 62.34 & 63.89 & 18.51 & 60.24 & 75.28 & 1.065 & 20 \\
\hline EGARCH-GED & 52.35 & 40.76 & 61.64 & 61.33 & 18.38 & 59.76 & 75.22 & 1.049 & 19 \\
\hline IGARCH-GED & 53.34 & 41.53 & 62.20 & 43.48 & 18.57 & 60.71 & 76.08 & 1.003 & 12 \\
\hline GJRGARCH-GED & 52.96 & 41.14 & 62.25 & 74.68 & 18.46 & 59.90 & 75.99 & 1.099 & 21 \\
\hline
\end{tabular}

Views and opinions expressed in this article are the views and opinions of the author(s), Asian Economic and Financial Review shall not be responsible or answerable for any loss, damage or liability etc. caused in relation to/arising out of the use of the content. 